\title{
Atmospheric sulfur cycling in the southeastern Pacific - longitudinal distribution, vertical profile, and diel variability observed during VOCALS-REx
}

\author{
M. Yang ${ }^{1}$, B. J. Huebert ${ }^{1}$, B. W. Blomquist ${ }^{1}$, S. G. Howell ${ }^{1}$, L. M. Shank ${ }^{1}$, C. S. McNaughton ${ }^{1}$, A. D. Clarke ${ }^{1}$, \\ L. N. Hawkins ${ }^{2}$, L. M. Russell ${ }^{2}$, D. S. Covert ${ }^{3}$, D. J. Coffman ${ }^{4}$, T. S. Bates ${ }^{4}$, P. K. Quinn ${ }^{4}$, N. Zagorac ${ }^{5}$, A. R. Bandy ${ }^{5}$, \\ S. P. de Szoeke ${ }^{6}$, P. D. Zuidema ${ }^{7}$, S. C. Tucker ${ }^{8}$, W. A. Brewer ${ }^{9}$, K. B. Benedict ${ }^{10}$, and J. L. Collett ${ }^{10}$ \\ ${ }^{1}$ University of Hawaii at Manoa, Department of Oceanography, Honolulu, HI, USA \\ ${ }^{2}$ University of California San Diego, Scripps Institute of Oceanography, La Jolla, CA, USA \\ ${ }^{3}$ University of Washington, Department of Atmospheric Sciences, Seattle, WA, USA \\ ${ }^{4}$ National Oceanographic and Atmospheric Administration, Pacific Marine Environmental Laboratory, Seattle, WA, USA \\ ${ }^{5}$ Drexel University, Department of Chemistry, Philadelphia, PA, USA \\ ${ }^{6}$ Oregon State University, College of Oceanic and Atmospheric Sciences, Corvallis, OR, USA \\ ${ }^{7}$ University of Miami, Rosenstiel School of Marine and Atmospheric Science, Miami, FL, USA \\ ${ }^{8}$ Ball Aerospace and Technologies, Corp., Boulder, CO, USA \\ ${ }^{9}$ National Oceanographic and Atmospheric Administration, Earth System Research Laboratory, Boulder, CO, USA \\ ${ }^{10}$ Colorado State University, Department of Atmospheric Science, Fort Collins, CO, USA
}

Received: 10 January 2011 - Published in Atmos. Chem. Phys. Discuss.: 24 January 2011

Revised: 20 May 2011 - Accepted: 24 May 2011 - Published: 31 May 2011

\begin{abstract}
Dimethylsulfide (DMS) emitted from the ocean is a biogenic precursor gas for sulfur dioxide $\left(\mathrm{SO}_{2}\right)$ and non-sea-salt sulfate aerosols $\left(\mathrm{SO}_{4}^{2-}\right)$. During the VAMOSOcean-Cloud-Atmosphere-Land Study Regional Experiment (VOCALS-REx) in 2008, multiple instrumented platforms were deployed in the Southeastern Pacific (SEP) off the coast of Chile and Peru to study the linkage between aerosols and stratocumulus clouds. We present here observations from the NOAA Ship Ronald H. Brown and the NSF/NCAR C130 aircraft along $\sim 20^{\circ} \mathrm{S}$ from the coast $\left(70^{\circ} \mathrm{W}\right)$ to a remote marine atmosphere $\left(85^{\circ} \mathrm{W}\right)$. While $\mathrm{SO}_{4}^{2-}$ and $\mathrm{SO}_{2}$ concentrations were distinctly elevated above background levels in the coastal marine boundary layer (MBL) due to anthropogenic influence $(\sim 800$ and $80 \mathrm{pptv}$, respectively), their concentrations rapidly decreased west of $78^{\circ} \mathrm{W}(\sim 100$ and $25 \mathrm{pptv}$ ). In the remote region, entrainment from the free troposphere (FT) increased $\mathrm{MBL} \mathrm{SO}_{2}$ burden at a rate of $0.05 \pm 0.02 \mu$ moles $\mathrm{m}^{-2}$ day $^{-1}$ and diluted $\mathrm{MBL} \mathrm{SO}_{4}^{2}$ burden at a rate of $0.5 \pm 0.3 \mu$ moles $\mathrm{m}^{-2} \mathrm{day}^{-1}$, while the sea-to-air DMS flux $\left(3.8 \pm 0.4 \mu\right.$ moles $\left.\mathrm{m}^{-2} \mathrm{day}^{-1}\right)$ remained the pre-
\end{abstract}

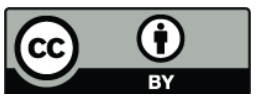

Correspondence to: B. J. Huebert (huebert@hawaii.edu) dominant source of sulfur mass to the MBL. In-cloud oxidation was found to be the most important mechanism for $\mathrm{SO}_{2}$ removal and in situ $\mathrm{SO}_{4}^{2-}$ production. Surface $\mathrm{SO}_{4}^{2-}$ concentration in the remote MBL displayed pronounced diel variability, increasing rapidly in the first few hours after sunset and decaying for the rest of the day. We theorize that the increase in $\mathrm{SO}_{4}^{2-}$ was due to nighttime recoupling of the MBL that mixed down cloud-processed air, while decoupling and sporadic precipitation scavenging were responsible for the daytime decline in $\mathrm{SO}_{4}^{2-}$.

\section{Introduction}

The ocean is the largest source of natural reduced sulfur gas to the atmosphere, most of which is in the form of dimethylsulfide (DMS), a volatile organic compound produced from phytoplankton. The annual global sea-to-air DMS emission is estimated to be 28.1 (17.6 34.4) Tg S (Lana et al., 2011), depending on the gas exchange and wind speed parameterization. In the atmosphere, DMS is principally oxidized by the hydroxyl radical $(\mathrm{OH})$ to a number of products, including sulfur dioxide $\left(\mathrm{SO}_{2}\right)$. In addition to DMS oxidation, $\mathrm{SO}_{2}$ is formed from fossil fuel combustion and biomass burning

Published by Copernicus Publications on behalf of the European Geosciences Union. 
and removed from the marine boundary layer (MBL) through deposition to the ocean surface and oxidative reactions in the gas and aqueous phase. Gas phase oxidation of $\mathrm{SO}_{2}$ by $\mathrm{OH}$ and subsequent reactions with water vapor yield sulfuric acid vapor $\left(\mathrm{H}_{2} \mathrm{SO}_{4(\mathrm{~g})}\right)$, which usually condenses upon preexisting aerosol surfaces and increases non-sea-salt sulfate aerosol $\left(\mathrm{SO}_{4}^{2-}\right)$ mass. Under specific conditions (usually high $\mathrm{H}_{2} \mathrm{SO}_{4(\mathrm{~g})}$ and water vapor as well as low aerosol surface area), $\mathrm{H}_{2} \mathrm{SO}_{4(\mathrm{~g})}$ may undergo gas-to-particle conversion and nucleate new nm-sized particles, which then grow by condensation and coagulation (Perry et al., 1994; Clarke et al., 1998).

Generally the oxidation of $\mathrm{SO}_{2}$ in the aqueous phase, which also leads to fine (submicron) $\mathrm{SO}_{4}^{2-}$ aerosols, is much faster than in the gas phase. Due to dissolution of carbon dioxide and other acids, cloud water typically has a $\mathrm{pH}$ under 5 (Chameides, 1984), which makes hydrogen peroxide $\left(\mathrm{H}_{2} \mathrm{O}_{2}\right)$ the principal oxidant of $\mathrm{SO}_{2}$ in cloud. Hegg (1985) suggested cloud processing to be the most important mechanism for the conversion from $\mathrm{SO}_{2}$ to $\mathrm{SO}_{4}^{2-}$. Sea-salt aerosols from wave breaking account for the majority of the coarse (supermicron) number as well as total aerosol mass, and tend to be more basic than fine $\mathrm{SO}_{4}^{2-}$ aerosols because of the initial alkalinity of seawater $(\mathrm{pH} \sim 8.1)$ and its carbonate buffering capacity. Because the reaction rate between $\mathrm{SO}_{2}$ and ozone $\left(\mathrm{O}_{3}\right)$ is greatly accelerated at high $\mathrm{pH}$ (Hoffmann, 1985), some authors postulated $\mathrm{O}_{3}$ oxidation in seasalt aerosols to be a significant sink of $\mathrm{SO}_{2}$ and source of $\mathrm{SO}_{4}^{2-}$ mass (Sievering et al., 1991; Faloona et al., 2010).

In addition to affecting atmospheric chemistry, $\mathrm{SO}_{4}^{2-}$ aerosols are climatically important because they alter the global radiative balance directly by scattering light (Charlson et al., 1992) and indirectly by controlling the optical properties, areal extent, and lifetimes of clouds by acting as cloud condensation nuclei $(\mathrm{CCN})$. In a remote marine environment where $\mathrm{CCN}$ represent a substantial fraction of the aerosol number, a gap at $70 \sim 80 \mathrm{~nm}$ in diameter in the number distribution is often observed, which has been coined the "Hoppel minimum" (Hoppel et al., 1986). Aerosols smaller than this minimum are unactivated, while larger aerosols have been activated and grown through cloud processing into the accumulation mode $(0.1 \sim 1 \mu \mathrm{m})$.

Charlson et al. (1987) presented a theory postulating a negative feedback loop from enhanced phytoplankton growth and DMS efflux in a warming climate to a decrease in incident radiation (and hence cooling) due to greater albedo of marine clouds from more $\mathrm{SO}_{4}^{2-}$ derived CCN. The effects of naturally derived $\mathrm{SO}_{4}^{2-}$ on clouds are expected to be greatest in areas deprived of CCN (Twomey, 1991), such as over the remote ocean in the relatively pristine Southern Hemisphere.

The Southeastern Pacific (SEP) is a region characterized by large-scale subsidence associated with subtropical anticyclonic flow, coastal upwelling of cold water driven by Ekman transport, and a large stratocumulus cloud deck capped by a strong inversion layer (Bretherton et al., 2004). The inversion confines surface-derived scalars to the MBL, separated from the stable, dry, and relatively quiescent free troposphere (FT). The stratocumulus topped MBL is shallow near the coast $(\sim 1 \mathrm{~km})$ with more broken clouds. Away from shore, the MBL deepens with thicker clouds and more extensive precipitation in the form of drizzle. Satellite observations show frequent hundred-kilometer sized openings in the stratocumulus cloud deck. Termed "pockets of open cells" (POCs), these features persist for a timescale of a day and advect with the mean wind (Stevens et al., 2005). The geographical gradient in cloud properties as well as the formation and evolution of POCs likely depend on the availability of aerosols that can act as $\mathrm{CCN}$ and suppress drizzle, and drizzle that in turn removes said aerosols. The coastal regions of Chile and Peru are influenced by pollution emissions of $\mathrm{SO}_{4}^{2-}$ and $\mathrm{SO}_{2}$ from fossil fuel consumption and processing of copper ores. Because the prevailing wind direction at the surface is from S/SE along the Andes mountain range, anthropogenic influence decreases quickly away from shore, where a greater contribution to the $\mathrm{SO}_{4}^{2-}$ burden and larger fraction of $\mathrm{CCN}$ likely originate from DMS.

In this paper, we will look at the longitudinal distributions of $\mathrm{SO}_{2}$ and $\mathrm{SO}_{4}^{2-}$ in VOCALS-REx to evaluate the impact of coastal pollution on the SEP. To assess the importance of entrainment relative to surface sources, we will focus on the vertical aircraft profiles of gases and aerosols in the remote region. Finally, following up on the DMS budget presented in Yang et al. (2009), we will examine the diel budgets of $\mathrm{SO}_{2}$ and $\mathrm{SO}_{4}^{2-}$.

\section{Experimental}

During VOCALS-REx in 2008 (Wood et al., 2011), the National Oceanographic and Atmospheric Administration (NOAA) ship Ronald H. Brown (RHB) was operating in the SEP from 20 October to 3 November and from 10 November to 11 December. The ship made multiple transects between the coastal city of Arica at $18^{\circ} \mathrm{S}, 70^{\circ} \mathrm{W}$ and the remote marine region near the Woods Hole Oceanographic Institution (WHOI) Improved Meteorology (IMET) moored buoy at $20^{\circ} \mathrm{S}, 85^{\circ} \mathrm{W}$. The National Science Foundation (NSF)/National Center for Atmospheric Research (NCAR) C-130 aircraft flew 14 research flights (RF) out of Arica between October 15 and November 15. Eight flights were dedicated to survey the $20^{\circ} \mathrm{S}$ line to as far as $86^{\circ} \mathrm{W}$, four were designed to study the structures and evolution of POCs, and two were parallel to the coast between $20^{\circ} \mathrm{S}$ and $30^{\circ} \mathrm{S}$. For the $20^{\circ} \mathrm{S}$ surveying flights, the aircraft typically flew $10-\mathrm{min}$ level legs near the surface, in the mid MBL, at cloud level, and above clouds. Profiles from the surface to $\sim 4 \mathrm{~km}$ were frequently performed. 


\subsection{RHB}

Measurements of atmospheric DMS concentration at 20 $\mathrm{Hz}$ and hourly sea-to-air flux by eddy covariance during VOCALS-REx were outlined by Yang et al. (2009). Instrument design and flux computation were detailed by Blomquist et al. (2010). Seawater DMS was taken from the ship's uncontaminated seawater line at $\sim 5.5 \mathrm{~m}$ below the ocean surface, extracted by a purge-and-trap method, and analyzed by gas chromatography with a sub-nM detection limit every 15 30 min (Bates et al., 2000).

Aerosol chemical compositions and size distributions were measured by the Pacific Marine Environmental Laboratory through an isokinetic inlet on the forward deck of the ship. Submicron and supermicron aerosols were collected on a two-stage multi-jet cascade impactor ( $50 \%$ aerodynamic cutoff diameters of 1.1 and $10 \mu \mathrm{m}$ ) over $2 \sim 23 \mathrm{~h}$. In addition to providing gravimetric mass, collected aerosols were analyzed for soluble concentrations of sodium $\left(\mathrm{Na}^{+}\right)$, potassium $\left(\mathrm{K}^{+}\right)$, calcium $\left(\mathrm{Ca}^{2+}\right)$, magnesium $\left(\mathrm{Mg}^{2+}\right)$, ammonia $\left(\mathrm{NH}_{4}^{+}\right)$, methane sulfonate $\left(\mathrm{MSA}^{-}\right)$, chloride $\left(\mathrm{Cl}^{-}\right)$, bromide $\left(\mathrm{Br}^{-}\right)$, nitrate $\left(\mathrm{NO}_{3}^{-}\right)$, sulfate, and oxalate $\left(\mathrm{Ox}^{2-}\right)$ using ion chromatography (Bates et al., 2008). Non-sea-salt$\mathrm{SO}_{4}^{2-}$ and $\mathrm{Cl}^{-}$deficit were calculated by subtracting seasalt components from total concentrations. An Aerodyne quadrupole aerosol mass spectrometer (Q-AMS) was used to continuously measure submicron particulate concentrations of $\mathrm{SO}_{4}^{2-}, \mathrm{NO}_{3}^{-}, \mathrm{NH}_{4}^{+}$, and organic matter (Hawkins et al., 2010). The AMS quantified non-refractory aerosols (those vaporizing at $600^{\circ} \mathrm{C}$ ), thus excluded mineral dust, elemental carbon, and sea-salt. AMS sulfate concentration agreed exceptionally well with collocated submicron filter measurements of $\mathrm{SO}_{4}^{2-}$ (slope of 1.09 and $r^{2}$ of 0.88 ) and showed a high degree of correlation with integrated submicron aerosol volume ( $r^{2}$ of 0.86 ). Aerosol size distributions from $0.02 \sim 10 \mu \mathrm{m}$ were obtained by merging spectra from a differential mobility particle sizer and an aerodynamic particle sizer at a regulated (APS) RH of $60 \%$ (Bates et al., 2008). Except for filter samples, above measurements were reported at 5-min intervals.

The inversion height $\left(Z_{\mathrm{i}}\right)$ was determined from radiosondes launched every six hours from the ship by the NOAA Earth System Research Laboratory (de Szoeke et al., 2008). During the second half of VOCALS-REx, cloud fraction and cloud top height were determined from a W-band radar. Precipitation rate was continuously estimated by a shipboard optical rain gauge. The surface-based mixed layer height (MLH), useful for determining boundary layer coupling and decoupling, was estimated hourly from a High Resolution Doppler Lidar $(2 \mu \mathrm{m})$ from velocity variance (turbulence) profiles and aerosol backscatter gradient (Tucker et al., 2009). The vertically-integrated liquid water content, or liquid water path $\left(L_{\mathrm{WP}}\right)$, was estimated at 10-min intervals from a two-channel microwave radiometer by University of Miami using a physical retrieval similar to Zuidema et al. (2005) that takes cloud temperature into account.

\subsection{C-130}

DMS and $\mathrm{SO}_{2}$ were measured at $1 \mathrm{~Hz}$ using an atmospheric pressure ionization mass spectrometer at a pptv detection limit by Drexel University (Bandy et al., 2002; Thornton et al., 2002). Both DMS and $\mathrm{SO}_{2}$ on the $\mathrm{C}-130$ were sampled from backward facing inlets that should not be affected by cloud droplets. Within clouds, measurements of those gases represented interstitial concentrations.

The University of Hawaii aerosol instruments were typically located behind a low turbulence inlet (LTI) (Huebert et al., 2004b). Breaking up of cloud droplets upon collision on the wall of the inlet caused a cloud shattering artifact, or an increase in the measured number of particles. By excluding such incidents, aerosol data at cloud level were biased towards cloud free regions. A high resolution time-of-flight AMS on the C-130 measured aerosol concentration of $\mathrm{SO}_{4}^{2-}$, $\mathrm{NO}_{3}^{-}, \mathrm{NH}_{4}^{+}$, and organic matter every $10 \mathrm{~s}$. As with the AMS on the ship, the AMS on the C-130 sampled with a near-unity collection efficiency for aerosols up to $\sim 0.8 \mu \mathrm{m}$ in diameter and excluded large particles.

Aerosol size distributions at dried RH of $\sim 20 \%$ from diameters of 0.01 to $10 \mu \mathrm{m}$ were obtained at 1 -min intervals by merging spectra from a radial differential mobility analyzer $(0.01 \sim 0.20 \mu \mathrm{m})$, a TSI long differential mobility analyzer $(0.10 \sim 0.50 \mu \mathrm{m})$, a PMS laser optical particle counter $(0.12 \sim 8.0 \mu \mathrm{m})$, and a TSI 3321 aerodynamic particle sizer $(0.78 \sim 10.0 \mu \mathrm{m})$ (Howell et al., 2006). Direct comparisons between the distributions measured on the $\mathrm{C}-130$ and $R H B$ can only be qualitative in nature because of the different sampling strategies and airspeeds. At the dried environment of C-130 measurements, MBL aerosols had most likely undergone efflorescence and been approximately halved in size, whereas the already dry FT aerosols remained largely unchanged. The $R H B$ distributions, on the other hand, were measured at $\sim 60 \% \mathrm{RH}$, closer to the ambient RH of $\sim 70 \%$ and above the humidity threshold for efflorescence; the measured diameters thus should only be $\sim 10 \%$ smaller than ambient diameters.

Bulk cloud water was collected by Colorado State University every $\sim 10$ min with an Airborne Cloud Collector (Straub and Collett Jr., 2004; Straub et al., 2007), which had a $50 \%$ size cut diameter of $8 \mu \mathrm{m}$ and thus collected most cloud drops but excluded small, unactivated aerosols. Cloud water was analyzed for $\mathrm{pH}, \mathrm{SO}_{2} \cdot \mathrm{H}_{2} \mathrm{O}, \mathrm{HSO}_{3}^{-}$, and $\mathrm{SO}_{3}^{2-}$ (together $\mathrm{S}(\mathrm{IV})$ ), peroxides, etc. Details of cloud water sampling and analysis during VOCALS-REx were provided by Benedict et al. (2011). Aqueous cloud solute concentrations in $\mu \mathrm{M}$ are converted to atmospheric mixing ratios using cloud liquid water content $\left(L_{\mathrm{WC}}\right)$ measured by a Gerber Scientific Particulate Volume Monitor. 
Inversion heights determined based on potential temperature and dew point gradients from the C-130 sounding showed excellent agreement with those determined from potential temperature profiles from shipboard radiosondes. Because $Z_{\mathrm{i}}$ varied both with longitude and with the time of day, to average vertical distributions, altitude $(Z)$ is normalized to $Z_{\mathrm{i}}$, with $Z / Z_{\mathrm{i}}=1$ indicating the inversion. For FT averages along $20^{\circ} \mathrm{S}$, only observations within $1 \mathrm{~km}$ above $Z_{\mathrm{i}}$ are included.

\section{Observations}

Multiplatform observations of clouds, precipitation, and boundary layer structure during VOCALS-REx along $20^{\circ} \mathrm{S}$ were discussed in detail by Bretherton et al. (2010). Allen et al. (2011) described trace gas and aerosol compositions along the same latitude line based on measurements from multiple aircraft and the ship RHB. We separate the VOCALSREx sampling area longitudinally into the "near shore" $\left(70^{\circ} \mathrm{W} \sim 73^{\circ} \mathrm{W}\right)$ and 'offshore' regions $\left(73^{\circ} \mathrm{W} \sim 86^{\circ} \mathrm{W}\right)$. We further denote the 'remote' region as $78^{\circ} \mathrm{W} \sim 86^{\circ} \mathrm{W}$. Figure 1 shows the RHB cruise track color-coded by the DMS sea-toair flux; the dotted and solid lines indicate the offshore and remote regions. The stratification to these regions is based on aircraft observation of carbon monoxide (CO) and shipboard measurement of radon $(\mathrm{Rn})$, both indicators of continental influence. The lowest MBL CO concentration was found west of $78^{\circ} \mathrm{W}$ at $\sim 62 \mathrm{ppbv}$; $\mathrm{CO}$ increased to $\sim 73 \mathrm{ppbv}$ near the coast as a result of combustion, corresponding to elevated $\mathrm{SO}_{4}^{2-}$ concentrations. Hawkins et al. (2010) showed that the concentration of $\mathrm{Rn}$ (a radioactive decay product of uranium in rocks and soil) measured on the ship in the remote marine region was approximately half of the value by the coast. Three-day back trajectories by those authors showed that east of $75^{\circ} \mathrm{W}$, airmasses had been previously in contact with land south of the VOCALS-REx sampling area, near the Chilean capital Santiago. In contrast, west of $78^{\circ} \mathrm{W}$, air had originated from the remote South Pacific. Back trajectory analysis for MBL air by Allen et al. (2011) demonstrated very similar results. Figure 2 shows a typical $20^{\circ} \mathrm{S}$ survey flight by the C-130 (RF 03 on October 21). The flight track is colorcoded by $\mathrm{SO}_{2}$ concentration, with marker size corresponding to $\mathrm{SO}_{4}^{2-}$ concentration. The aircraft encountered more polluted air in two flights south of $\sim 22^{\circ} \mathrm{S}$, closer to Santiago, as well as on RF 14, the last flight by the C-130 in this campaign. Greater continental influence was also observed on the $R H B$ north of $\sim 15^{\circ} \mathrm{S}$, closer to Peru. For our " $20^{\circ} \mathrm{S}$ " averages, we limit the latitudinal range to $18^{\circ} \mathrm{S} \sim 22^{\circ} \mathrm{S}$ and exclude RF 14 from C-130 statistics. Because the aircraft usually took off from Arica in the early morning, reached $80 \sim 85^{\circ} \mathrm{W}$ at around sunrise, and returned to shore in the afternoon, spatial and temporal biases are inherent. We will thus mostly rely on ship observations for diel cycles and on aircraft observations for vertical structures.

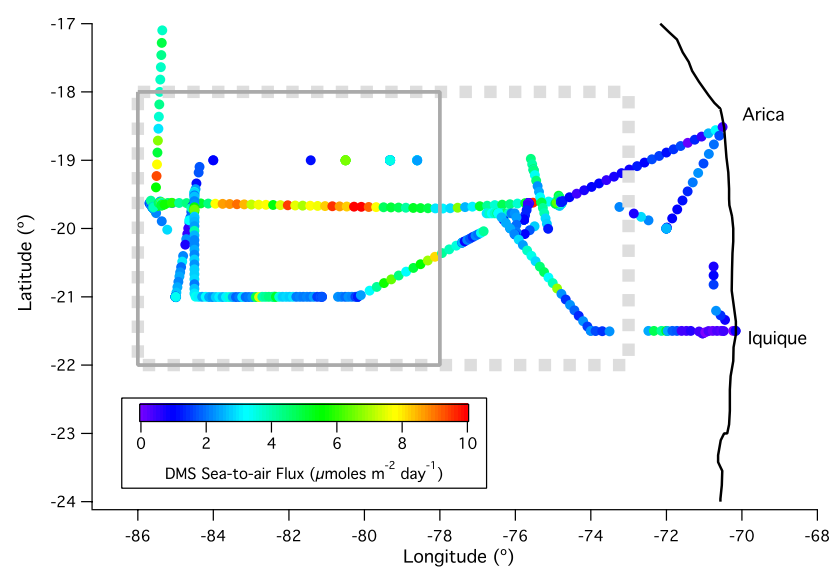

Fig. 1. VOCALS-REx cruise track color-coded by the DMS seato-air flux. The dotted and solid boxes indicate the VOCALS "offshore" and "remote" regions, respectively.

\subsection{Longitudinal distributions}

It was hypothesized prior to VOCALS-REx that coastal upwelling of cold, nutrient rich water stimulates growth of phytoplankton, which should lead to more seawater and hence atmospheric DMS at the coast than in the remote region. Observations of seawater DMS in VOCALS-REx were described in detail by Hind et al. (2011). In brief, we only observed enhanced seawater DMS in isolated pockets near shore. More often high seawater DMS was associated with the edge of an eddy or near a front between two water masses, where temperature and salinity changed markedly. On average along $20^{\circ} \mathrm{S}$, seawater DMS concentration was not substantially different between the coastal and the remote regions. Higher atmospheric DMS concentration and sea-to-air flux were observed away from the coast principally as a result of higher wind speed. At the same air-sea concentration difference in DMS (dictated by the seawater concentration), a higher wind speed generally leads to a higher transfer velocity, and hence a greater DMS flux out of the ocean (Huebert et al., 2004a; Yang et al., 2011).

Project average concentrations of DMS, $\mathrm{SO}_{2}$ and $\mathrm{SO}_{4}^{2-}$ along $20^{\circ} \mathrm{S}$ and in the MBL and FT are shown in Fig. 3. Pollution emission was unquestionably the major source of sulfur mass near shore, with $\mathrm{SO}_{2}$ and $\mathrm{SO}_{4}^{2-}$ concentrations elevated at $\sim 80$ and $\sim 800$ pptv in the MBL, respectively. Moving offshore towards the remote region, $\mathrm{SO}_{2}$ and $\mathrm{SO}_{4}^{2-}$ concentrations decreased rapidly to "background" levels. $\mathrm{SO}_{2}$ varied from flight to flight but was relatively well mixed with a mean (1 sigma) MBL concentration of $\sim 25$ (15) pptv, about $40 \%$ of the DMS concentration measured on the ship. We show later that the relatively low concentration of $\mathrm{SO}_{2}$ in the MBL was likely due to processing of air by stratocumulus clouds. $\mathrm{SO}_{4}^{2-}$ concentration was quite variable horizontally and vertically, which in part explains the difference 


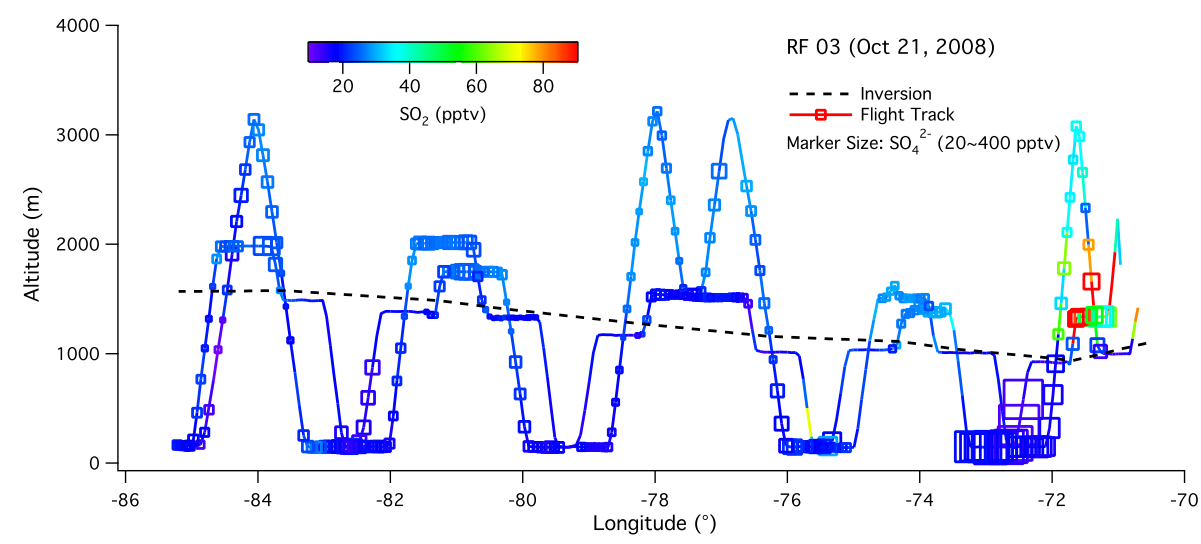

Fig. 2. A typical $20^{\circ} \mathrm{S}$ Survey flight by the C-130 (RF 03), with color indicating $\mathrm{SO}_{2}$ concentration and marker size representing aerosol $\mathrm{SO}_{4}^{2-}$ concentration. Level legs were typically flown near the surface, below the stratocumulus cloud deck, and above cloud, with occasional profiles to higher altitudes. Also included is the inversion height derived from C-130 profiles, which increased with distance away from shore.

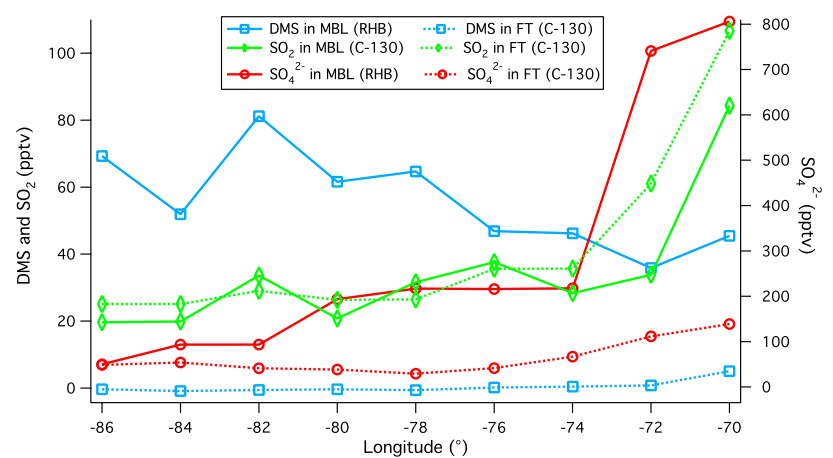

Fig. 3. Longitudinal trends in the atmospheric concentrations of DMS, $\mathrm{SO}_{2}$, and $\mathrm{SO}_{4}^{2-}$ along $20( \pm 2)^{\circ} \mathrm{S}$ in the MBL and $\mathrm{FT}$ (project means). $\mathrm{SO}_{2}$ and $\mathrm{SO}_{4}^{2-}$ were significantly elevated near shore due to pollution and rapidly decreased away from shore, where DMS was higher (see text for details).

between the averaged MBL concentrations from the $R H B$ 118 (85) pptv and C-130 60 (60) pptv in the remote MBL.

\subsection{Vertical structures away from shore}

The mean C-130 vertical profiles of temperature, dew point, potential temperature, $L_{\mathrm{WC}}, \mathrm{CO}, \mathrm{O}_{3}, \mathrm{DMS}, \mathrm{SO}_{2}$, and $\mathrm{SO}_{4}^{2-}$ for the offshore region before sunrise are shown in Fig. 4 . The elevated $L_{\mathrm{WC}}$ and sharp gradients in temperatures and dew point clearly indicate the inversion $\left(Z / Z_{\mathrm{i}}=1\right)$. The $\mathrm{C}$ 130 DMS concentration averaged zero in the FT, and appeared to be lower than that measured from the ship in the MBL for reasons that are not clear at the moment. $\mathrm{CO}$ and $\mathrm{O}_{3}$ showed increasing concentrations with $Z / Z_{\mathrm{i}}$, implying sources in the FT. Figure 5 shows the mean aerosol size distributions (number, surface area, and volume) from the
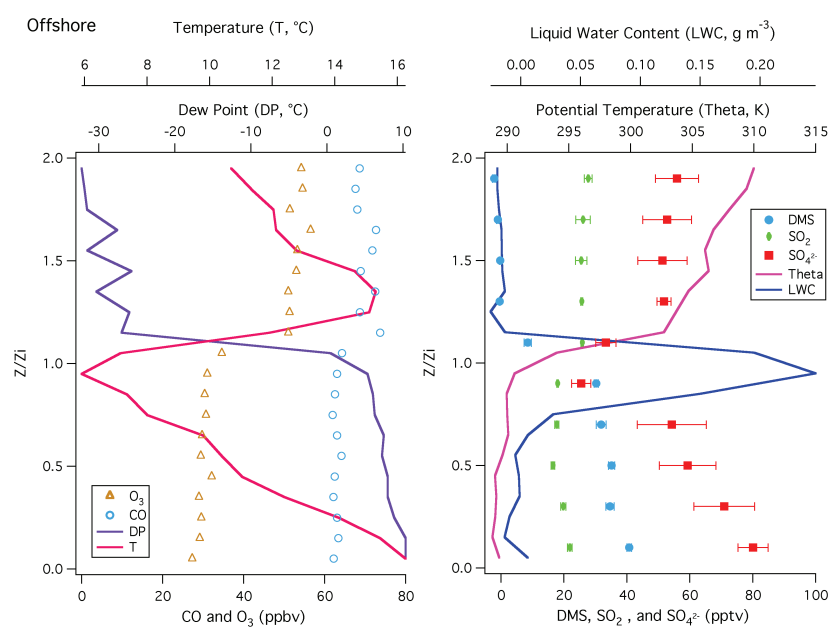

Fig. 4. Averaged vertical profiles of temperature, dew point, $\mathrm{CO}$, and $\mathrm{O}_{3}$ (left); DMS, $\mathrm{SO}_{2}, \mathrm{SO}_{4}^{2-}$ (with standard error of the mean), potential temperature, and liquid water content (right) in the offshore region before sunrise. $\mathrm{CO}, \mathrm{O}_{3}$, and $\mathrm{SO}_{2}$ concentrations were usually higher above the sharp inversion $\left(Z / Z_{\mathrm{i}}=1\right)$, while $\mathrm{SO}_{4}^{2-}$ concentration was most often greater below the inversion.

$\mathrm{C}-130$ in the remote region, stratified by $Z / Z_{\mathrm{i}}$. The low $\left(Z<0.2 Z_{\mathrm{i}} ; N=220\right)$ and mid $\left(0.4 Z_{\mathrm{i}}<Z<0.7 Z_{\mathrm{i}} ; N=86\right)$ MBL distributions were similar, with the Hoppel minimum at $\sim 70 \mathrm{~nm}$ indicating cloud processing. The upper MBL distribution $\left(0.8 Z_{\mathrm{i}}<Z<Z_{\mathrm{i}} ; N=493\right)$ as well as cloud level $\mathrm{SO}_{4}^{2-}$ concentration in Fig. 4 were biased towards cloud free and $\mathrm{POC}$ regions, as cloud shattering compromised measurements inside of clouds. A greater number of small particles was seen in the upper MBL, likely related to new particle nucleation. The above cloud distribution $\left(1.1 Z_{\mathrm{i}}<Z<1.3 Z_{\mathrm{i}}\right.$; $N=365$ ) was a superposition of two modes: a $30 \mathrm{~nm}$ background mode associated with low $\mathrm{CO}(<\sim 64 \mathrm{ppbv})$ and an 

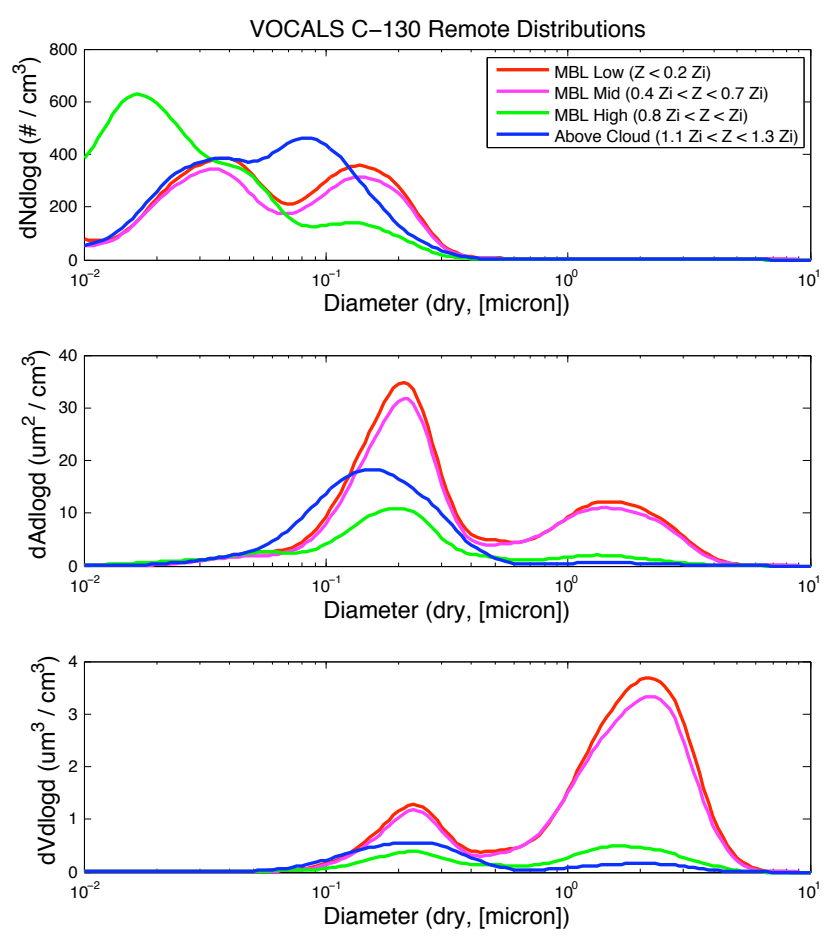

Fig. 5. Mean VOCALS C-130 remote particle number (top), surface area (middle), and volume distributions (bottom) at different normalized altitudes. The low and mid-MBL number distributions displayed the characteristic "Hoppel" minimum as a result of cloud processing. The above cloud number distribution was a superposition of two modes, corresponding to low and high CO concentrations, respectively.

$80 \mathrm{~nm}$ mode associated with high $\mathrm{CO}$ ( $>\sim 74 \mathrm{ppbv})$ that indicates long distance transport of pollution. Allen et al. (2011) showed similar trends in particle number distributions from the coast to the remote region.

\subsection{Diurnal cycles}

Turbulence at the inversion irreversibly entrains air from the FT into the MBL, which is largely balanced by horizontal wind divergence on a timescale of weeks. The rate of entrainment varies with radiative fluxes at the stratocumulus cloudtop. At night, longwave cooling causes greater convective instability, more turbulent mixing in the MBL, and increased entrainment (Lilly, 1968). During the day, shortwave heating of the cloud-top partially suppresses turbulence in the MBL, which reduces entrainment and causes the surface and the upper MBL to become decoupled (Nicholls, 1984). Evaporative cooling from falling drizzle droplets may further affect mixing in the MBL.

An array of measurements from the $R H B$ during VOCALS-REx illustrate the diel variability in the MBL; their offshore means over both cruise legs are shown in Fig. 6 . Vertical velocity profiles and MLH from the shipboard Lidar

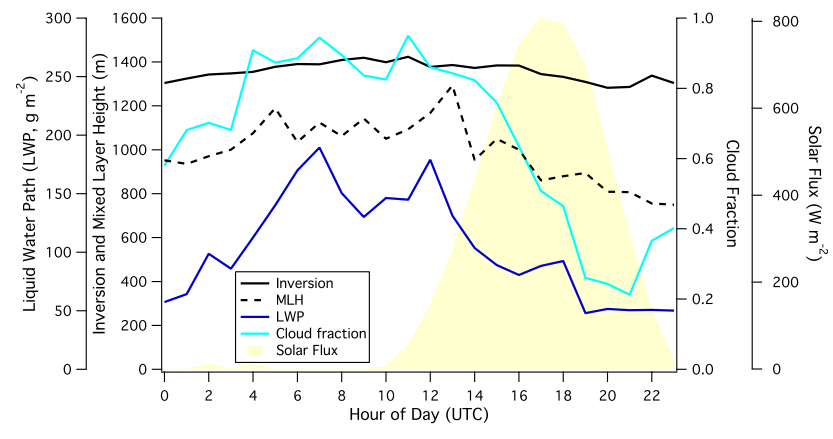

Fig. 6. Mean diel variations in inversion height, mixed layer height, liquid water path, and cloud fraction in the VOCALS offshore region. All of these variables were greater at night than during the day mostly due to the diel variability in the radiative properties associated with the stratocumulus cloud deck.

indicated a coupled MBL at night; as the instrument only reported MLH up to the cloud bottom, this measurement was generally an underestimate of the actual height of the wellmixed layer in the nighttime. Lidar measurements showed that the average velocity variance in the MBL was $\sim 50 \%$ lower during the daytime, with MLH only reaching 60 70\% of $Z_{\mathrm{i}}$ in the remote region, generally below the stratocumulus cloud bottom but above the lifting condensation level (LCL). While a cloud base well above the LCL is usually thought to indicate decoupling, the turbulence-based MLH measurement provides more direct information on whether surfacebased measurements are applicable up to $Z_{\mathrm{i}}$. Cloud fraction from the W-band radar averaged over $90 \%$ between midnight and sunrise and decreased to $20 \sim 30 \%$ in the afternoon. $L_{\text {WP }}$ peaked above $150 \mathrm{~g} \mathrm{~m}^{-2}$ over the same time span, more than three times the afternoon value. The optical rain gauge detected sporadic precipitation events up to $\sim 1 \mathrm{~mm} \mathrm{~h}^{-1}$, but typically at a lower value of $\sim 0.2 \mathrm{~mm} \mathrm{~h}^{-1}$. Precipitation was more intense and frequent west of $80^{\circ} \mathrm{W}$.

Surface concentrations of chemical tracers are affected by MBL dynamics. $\mathrm{O}_{3}$ averaged $26(R H B)$ and 52 ppbv (C-130) below and above $Z_{\mathrm{i}}$, respectively, with pronounced variability in the MBL. At night, $\mathrm{O}_{3}$ built up as a result of entrainment from the FT, whereas during the day, $\mathrm{O}_{3}$ decreased steadily because chemical destruction outpaced entrainment. Deposition to the ocean surface represents a small but continuous sink for $\mathrm{O}_{3}$ at all times. We can estimate the entrainment velocity $\left(\omega_{\mathrm{e}}\right)$ by balancing the MBL $\mathrm{O}_{3}$ build up over the first five hours after sunset (when the increase in concentration appeared to be linear) with entrainment and deposition fluxes, assuming no chemical source and loss at night (Clarke et al., 1996). Adopting a deposition velocity of $0.01 \mathrm{~cm} \mathrm{~s}^{-1}$ (derived from eddy covariance measurements of $\mathrm{O}_{3}$ during the Stratus 06 cruise in the SEP, J. Hare, personal communication, 2010), which is on the low end of published $\mathrm{O}_{3}$ rates, we calculate a nighttime $\omega_{\mathrm{e}}$ of $\sim 6 \mathrm{~mm} \mathrm{~s}^{-1}$, higher than $\omega_{\mathrm{e}} \sim 4 \mathrm{~mm} \mathrm{~s}^{-1}$ derived from the DMS budget by Yang et 

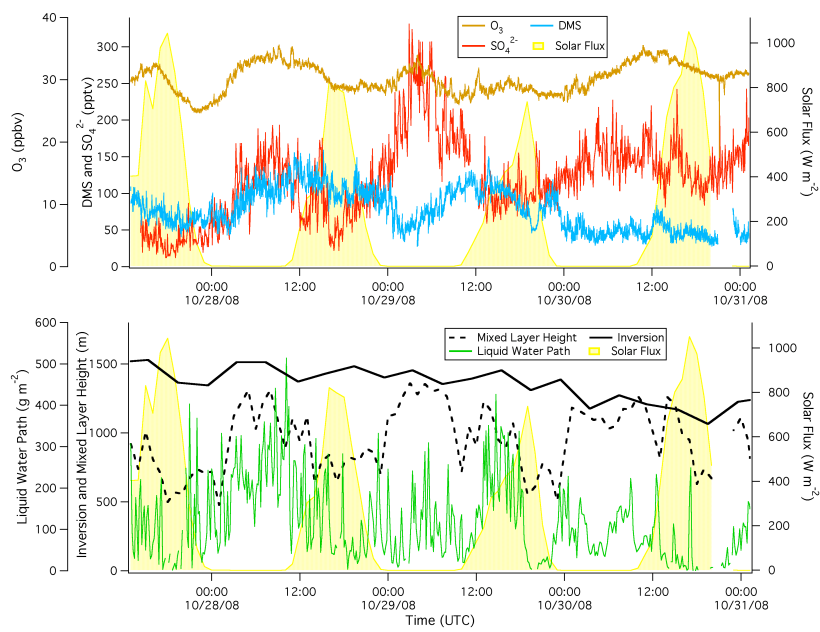

Fig. 7. Top panel: surface concentrations of $\mathrm{O}_{3}$, DMS, and $\mathrm{SO}_{4}^{2-}$ from 28 31 October; bottom panel: liquid water path, mixed layer height, and inversion height for the same period. $\mathrm{SO}_{4}^{2-}$ frequently decreased during the day and peaked at night, as did $\mathrm{O}_{3}$. MLH approached $Z_{i}$ at night, suggesting a well-mixed MBL, whereas during the day MLH was only about half of $Z_{i}$, indicating decoupling.

al. (2009). Moreover, $\mathrm{O}_{3}$ concentration was generally higher in the north $\left(\sim 30 \mathrm{ppbv}\right.$ at $\left.19^{\circ} \mathrm{S}\right)$ than in the south $(\sim 20 \mathrm{ppbv}$ at $21^{\circ} \mathrm{S}$ ), implying a gradient along the mean wind. Using a greater deposition velocity or accounting for this potential advective flux would require an even higher $\omega_{\mathrm{e}}$ to balance the $\mathrm{O}_{3}$ budget. This inconsistency between $\omega_{\mathrm{e}}$ derived from $\mathrm{O}_{3}$ and $\omega_{\mathrm{e}}$ from other scalars warrants future investigation, and will not be explored further here.

$\mathrm{SO}_{4}^{2-}$ concentrations measured by the AMS on the $R H B$ displayed large diel variability, as exemplified by the period from 28 to 31 October when the ship was steaming eastward at $5.7 \mathrm{~m} \mathrm{~s}^{-1}$ from $85^{\circ} \mathrm{W}$ to $75^{\circ} \mathrm{W}$ (Fig. 7). $\mathrm{SO}_{4}^{2-}$ increased from $20 \sim 30$ pptv to over 150 300 pptv over the first few hours after sunset, peaking at around 04:00 UTC (01:00 a.m. local), with $\mathrm{O}_{3}$ also increasing at the same times presumably due to greater entrainment of FT air. $\mathrm{SO}_{4}^{2-}$ then declined over the rest of the day, with the sharpest decrease in the early morning, when the precipitation peaked $\left(\sim 0.3 \mathrm{~mm} \mathrm{~h}^{-1}\right)$ and the MBL started to become decoupled, as evidenced from the difference between the $Z_{\mathrm{i}}$ and MLH. The diel variability in surface $\mathrm{SO}_{4}^{2-}$ concentration is perhaps more clearly illustrated by looking at its VOCALS remote mean over both cruise legs (Fig. 8), along with diel cycles in DMS and $\mathrm{O}_{3}$. The nighttime increase and daytime decrease in DMS were due to continuous sea-to-air flux and daytime oxidative loss, as explained in detail by Yang et al. (2009). For $\mathrm{O}_{3}$, the relative increase over the first five hours after sunset was $\sim 2 \%$ $\mathrm{h}^{-1}$. Over the same time span, the relative increase in $\mathrm{SO}_{4}^{2-}$ was about four times faster. $\mathrm{O}_{3}$ and DMS both decreased after sunrise due to photochemical reactions, whereas $\mathrm{SO}_{4}^{2-}$ decreased much sooner.

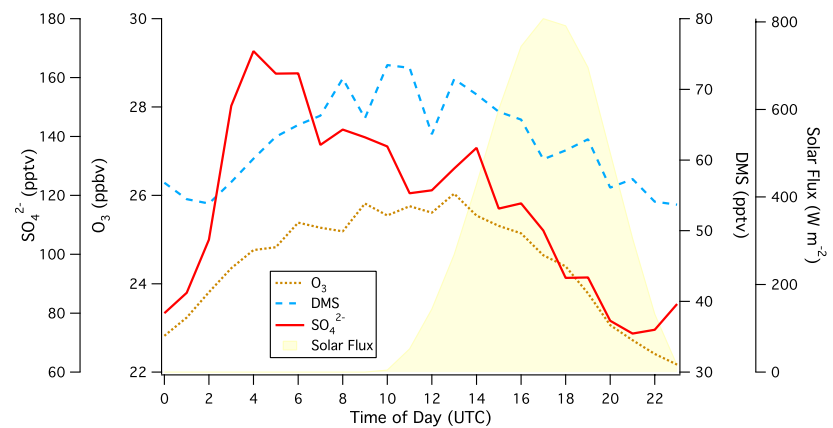

Fig. 8. Mean diel variations in $\mathrm{DMS}, \mathrm{O}_{3}$, and $\mathrm{SO}_{4}^{2-}$ surface concentrations in the VOCALS remote region. While increasing concentrations after sunset in both $\mathrm{O}_{3}$ and $\mathrm{SO}_{4}^{2-}$ suggest higher concentrations above, the respective sources and physical mechanisms involved were likely different, as implied by their distinct diel profiles (see text for more details).

The rapid increase in $\mathrm{SO}_{4}^{2-}$ after sunset is in contrast with previous measurements in the Equatorial Pacific (Huebert et al., 1996), which showed a daytime build up of $\mathrm{SO}_{4}^{2-}$ from $\mathrm{SO}_{2}$ oxidation by $\mathrm{OH}$. Moreover, the observed increase in $\mathrm{SO}_{4}^{2-}$ during VOCALS-REx is much too fast to be caused by any chemical mechanisms alone. $\mathrm{As}_{3}$ was increasing at the same time, a plausible explanation invokes a $\mathrm{SO}_{4}^{2-}$ source above, such as in-cloud oxidation of $\mathrm{SO}_{2}$. This source could not significantly increase the surface concentration during the day due to decoupling of the MBL. As the MBL became recoupled after sunset, air rich in $\mathrm{SO}_{4}^{2-}$ would be mixed downwards, increasing the surface concentration. Precipitating droplets that evaporate while falling return aerosols to the MBL, but likely at greater sizes than before being scavenged. This process could further speed up the transport of $\mathrm{SO}_{4}^{2-}$ from cloud level to the surface. Unfortunately, per flight plans, the C-130 did not sample the remote region at this time of the day to directly verify this proposed mechanism.

Aerosol size distributions measured on the $R H B$ are stratified according to the time of day in Fig. 9. In the remote region, the largest accumulation mode was measured in the evening (22:00 06:00 UTC; $N=1455)$, consistent with AMS SO$~_{4}^{2-}$ observations. The nuclei and coarse modes appeared to be larger in the late afternoon (14:00 22:00 UTC; $N=1478)$ than in the early morning $(06: 00 \sim 14: 00$ UTC; $N=1488$ ), presumably due to photochemistry and the slightly higher winds during the day, respectively.

\section{Discussion}

To better understand the sulfur cycling in the SEP, we examine the budgets of $\mathrm{SO}_{2}$ and $\mathrm{SO}_{4}^{2-}$ in the remote region. The conservation equation for any chemical species, $S$, in 

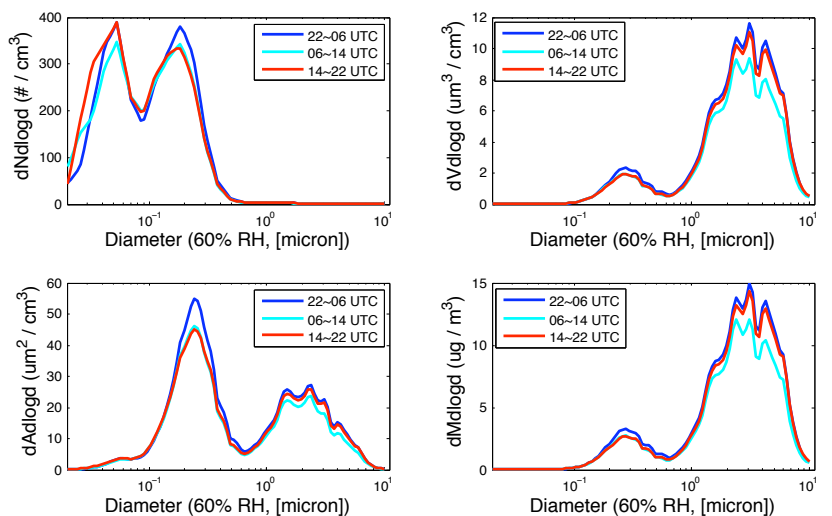

Fig. 9. Mean VOCALS RHB particle number (top left), surface area (bottom left), volume (top right), and mass distributions (bottom right) stratified by the time of day in the remote region. The accumulation mode (dominated by $\mathrm{SO}_{4}^{2-}$ ) was clearly the largest from around sunset to a few hours before sunrise (22:00 06:00 UTC), consistent with the observed increase in $\mathrm{SO}_{4}^{2-}$ by the shipboard AMS. More nuclei and coarse mode particles were seen in the afternoon (14:00 22:00 UTC) than in the early morning (06:00 14:00 UTC).

the MBL is represented below, with the overbar representing an average in time and/or space:

$$
\frac{\partial \bar{S}}{\partial t}+\bar{u} \frac{\partial \bar{S}}{\partial x}+\frac{\partial \overline{S^{\prime} w^{\prime}}}{\partial z}=P-L
$$

The terms on the left are the time-rate of change in the concentration of $S$, horizontal advection due to gradients along the mean wind, and vertical flux divergence, respectively. In situ production and loss of $S$ are represented by $P$ and $L$ on the right hand side (RHS).

In the following sections, we will first briefly introduce and approximate each of the rates in the budget equations of $\mathrm{SO}_{2}$ and $\mathrm{SO}_{4}^{2-}$. In the end, we will derive implied diel cycles of $\mathrm{SO}_{2}$ and $\mathrm{SO}_{4}^{2-}$ based on those rates and adjust the least certain terms if necessary to achieve steady state mass balance. Through multi-variate fitting, Yang et al. (2009) showed that the horizontal gradient in atmospheric DMS concentration mostly lay in the E-W direction, orthogonal to the prevailing wind along the Andes $\left(\sim 150^{\circ}\right)$; the advective flux of DMS was thus negligible. Analogous multi-variate analysis of $\mathrm{SO}_{2}$ and $\mathrm{SO}_{4}^{2-}$ concentrations in the remote $\mathrm{MBL}$ over the entire project resulted in similarly small advective fluxes on average because gradients in $\mathrm{SO}_{2}$ and $\mathrm{SO}_{4}^{2-}$ were also largely longitudinal. We will therefore ignore advection in the calculations below.

\subsection{Sulfur dioxide budget}

Observations from the Equatorial Pacific first demonstrated a quantitative anti-correlation between DMS and $\mathrm{SO}_{2}$ as a result of the oxidation of DMS by the $\mathrm{OH}$ radical (Bandy et al., 1996). Integrating Eq. (1) from the surface to $Z_{\mathrm{i}}$ for $\mathrm{SO}_{2}$ leads to:

$$
\begin{aligned}
& \frac{\partial\left\langle\overline{\mathrm{SO}_{2}}\right\rangle}{\partial t}=F_{\mathrm{SO}_{2}, 0}-F_{\mathrm{SO}_{2}, Z_{\mathrm{i}}}+\left\langle P_{\mathrm{SO}_{2}}\right\rangle-\left\langle L_{\mathrm{SO}_{2}, \mathrm{OH}}\right\rangle \\
& \quad-\left\langle L_{\mathrm{SO}_{2}, \text { cloud }}\right\rangle-\left\langle L_{\mathrm{SO}_{2}, \text { aero }}\right\rangle
\end{aligned}
$$

Here angular brackets denote column integrals, with every term now in units of flux (e.g. $\mu$ moles $\mathrm{m}^{-2}$ day $^{-1}$ ). Flux divergence is separated into the first and second terms on the RHS, representing $\mathrm{SO}_{2}$ surface flux at the ocean surface (deposition) and the combined effect of entrainment at $Z_{\mathrm{i}}$ and wind divergence. $P_{\mathrm{SO}_{2}}$ is in situ production of $\mathrm{SO}_{2}$ from DMS, while the last three terms represent losses due to $\mathrm{OH}$, in clouds, and in aerosols, respectively. Wet deposition is not considered for $\mathrm{SO}_{2}$ because of its relatively low solubility in acidic hydrometeors.

\subsection{1 $\mathrm{SO}_{2}$ dry deposition}

The dry depositional flux of $\mathrm{SO}_{2}$ to the ocean may be related to the $\mathrm{SO}_{2}$ concentration near the surface $\left(\left[\mathrm{SO}_{2,0}\right]\right)$ and a deposition velocity $\left(V_{\text {dep }}\right)$ :

$F_{\mathrm{SO}_{2,0}}=-V_{\text {dep }}\left[\mathrm{SO}_{2,0}\right]$

The seawater concentration is irrelevant here for the air-sea exchange of $\mathrm{SO}_{2}$ due to its high reactivity in the seawater (Fairall et al., 2007). At a typical VOCALS-REx wind speed of $6 \mathrm{~m} \mathrm{~s}^{-1}$, models based on atmospheric resistance predict $V_{\text {dep }} \approx 5 \mathrm{~mm} \mathrm{~s}^{-1}$ (Wesely and Hicks, 1977; Fairall et al., 2007). Aircraft eddy covariance measurements from a recent Equatorial project yielded a somewhat lower $V_{\text {dep }}$ of $3 \sim 4 \mathrm{~mm} \mathrm{~s}^{-1}$ at this wind speed (Faloona et al., 2010). With $V_{\text {dep }}=4 \pm 1 \mathrm{~mm} \mathrm{~s}^{-1}$ and $\left[\mathrm{SO}_{2,0}\right]=35 \mathrm{pptv}$, the dry deposition flux was $0.6 \pm 0.1 \mu$ mole $\mathrm{m}^{-2} \mathrm{day}^{-1}$, equivalent to $0.4 \pm 0.1 \mathrm{pptv} \mathrm{h}^{-1}$ for a $1.3 \mathrm{~km}$ deep MBL. We will show later that dry deposition was a minor term in the $\mathrm{SO}_{2}$ budget, such that the uncertainty in $V_{\text {dep }}$ does not significantly alter our conclusions.

\subsection{2 $\mathrm{SO}_{2}$ entrainment}

The net flux of $\mathrm{SO}_{2}$ into the MBL resulting from entrainment at $Z_{\mathrm{i}}$ and wind divergence in the MBL may be formulated as the entrainment velocity, $\omega_{\mathrm{e}}$, multiplied by the concentration jump in $\mathrm{SO}_{2}$ across the inversion assuming a constant MBL depth over weeks (Lilly, 1968), with $Z_{\mathrm{i}}^{-}$and $Z_{\mathrm{i}}^{+}$indicating below and above $Z_{\mathrm{i}}$ :

$$
F_{\mathrm{SO}_{2, Z_{\mathrm{i}}}}=\omega_{\mathrm{e}}\left\{\left[\mathrm{SO}_{2, Z_{i}^{-}}\right]-\left[\mathrm{SO}_{2, Z_{i}^{+}}\right]\right\}
$$

In the remote region, the concentration of $\mathrm{SO}_{2}$ at cloud level was reduced to $\sim 18 \mathrm{pptv}$ due to cloud processing; at $\sim 26 \mathrm{pptv}, \mathrm{SO}_{2}$ in the FT likely originated from long distance transport of anthropogenic and natural emissions. From the nighttime budget analysis of DMS in the offshore region, 
Yang et al. (2009) estimated an $\omega_{\mathrm{e}}$ of $\sim 4 \mathrm{~mm} \mathrm{~s}^{-1}$, matching the diel mean estimated from climatological and mixed-layer models for this region (Wood and Bretherton, 2004; Caldwell et al., 2005). Using the Weather and Research Forecast model and solving for the change of MBL depth over time, Rahn and Garreaud (2010) derived a similar mean $\omega_{\mathrm{e}}$ value as the residual for VOCALS-REx. Using a mean $\omega_{\mathrm{e}}$ of $4 \mathrm{~mm} \mathrm{~s}^{-1}$ and the concentration jump between the FT and the cloud level (26 and $18 \mathrm{pptv}$ ), entrainment increased MBL $\mathrm{SO}_{2}$ burden at an approximate rate of $0.1 \mu$ mole $\mathrm{m}^{-2} \mathrm{day}^{-1}$, or $\sim 0.1 \mathrm{pptv} \mathrm{h}^{-1}$.

\subsection{3 $\mathrm{SO}_{2}$ production from $\mathrm{DMS}$}

DMS is principally oxidized by $\mathrm{OH}$ in two separate pathways: $\mathrm{H}$-atom abstraction and $\mathrm{OH}$-addition (Yin et al., 1990). The abstraction channel is favored at high temperatures and essentially all leads to $\mathrm{SO}_{2}$, while the addition channel speeds up at low temperatures and leads to MSA, dimethylsulfoxide (DMSO), and also $\mathrm{SO}_{2}$. From the DMS budget, Yang et al. (2009) estimated a diel mean effective $\mathrm{OH}$ concentration of $1.4 \pm 0.2 \times 10^{6} \mathrm{OH}$ molecules $\mathrm{cm}^{-3}$, peaking at $\sim 5 \times 10^{6}$ molecules $\mathrm{cm}^{-3}$ at noontime. Representing the conversion efficiency from DMS to $\mathrm{SO}_{2}$ as $\gamma$, which typically ranges from $0.6 \sim 0.9$ and is recommended to be $0.7( \pm 0.2)$ by Faloona (2009), the in situ production of $\mathrm{SO}_{2}$ is:

$$
\left\langle P_{\mathrm{SO}_{2}}\right\rangle=\gamma\left(k_{\mathrm{OH}+\mathrm{DMS}}[\mathrm{OH}]\langle\overline{\mathrm{DMS}}\rangle\right)
$$

Here $k_{\mathrm{OH}+\mathrm{DMS}}$ is the total second order rate constant of the DMS-OH reaction (sum of the abstraction and addition channels). At an average MBL temperature of $\sim 13^{\circ} \mathrm{C}$ in VOCALS-REx, $k_{\mathrm{OH}} \approx 7.9 \times 10^{-12} \mathrm{~cm}^{3} \mathrm{molec}^{-1} \mathrm{~s}^{-1}$, with the abstraction pathway accounting for $60 \%$ of the total oxidation (Sander et al., 2006).

MSA largely resides in the particulate phase; in VOCALSREx, most of the MSA was found in the fine mode according to filter measurements. Since MSA is entirely produced from DMS whereas $\mathrm{SO}_{4}^{2-}$ can have both natural and anthropogenic origins, the MSA: $\mathrm{SO}_{4}^{2-}$ ratio can be used to infer branching in DMS oxidation as well as the natural contribution to the sulfur burden (Bates et al., 1992). The submicron MSA: $\mathrm{SO}_{4}^{2-}$ ratio in this study varied between $0.04 \sim 0.15$ (mean of 0.08 ) and closely followed the DMS concentration (Fig. 10). If MSA were the only other major oxidation product of DMS besides $\mathrm{SO}_{2}$ (and ultimately $\mathrm{SO}_{4}^{2-}$ ), and if all of the $\mathrm{SO}_{4}^{2-}$ in the remote region were formed from DMS, assuming equal lifetime for MSA and $\mathrm{SO}_{4}^{2-}$ due to precipitation scavenging would imply $\gamma \approx 0.9$ for a MSA: $\mathrm{SO}_{4}^{2-}$ ratio of 0.1. Accounting for DMSO, the other major product from the addition channel but not measured during the campaign, would reduce $\gamma$. Using a range of $0.7 \sim 0.9$ in $\gamma$ led to a diel average $\mathrm{SO}_{2}$ gas phase production of $2.2 \sim 2.8 \mu$ moles $\mathrm{m}^{-2} \mathrm{day}^{-1}$, or $1.8 \sim 2.3 \mathrm{pptv} \mathrm{h}^{-1}$.

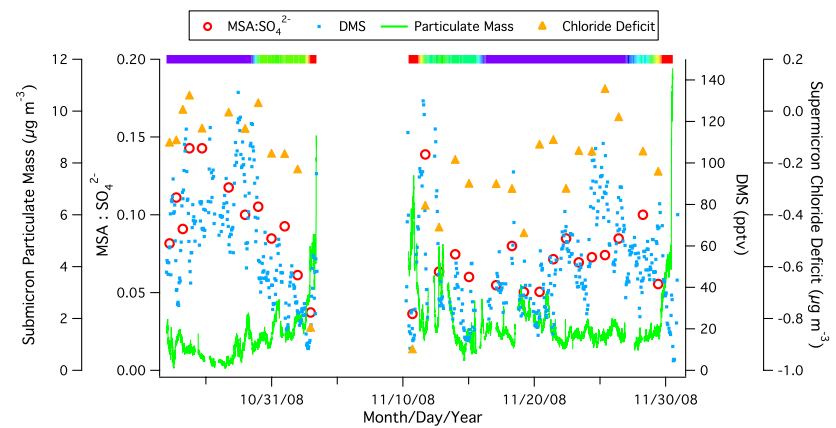

Fig. 10. Time-series of submicron particulate mass, MSA:SO $\mathrm{SO}_{4}^{2-}$ ratio, DMS, and supermicron chloride deficit. The horizon bar near the top of the graph is color-coded by longitude, with purple and red indicating the remote and near shore regions, respectively, and green representing the area in between. The MSA:SO ${ }_{4}^{2-}$ ratio follows DMS concentration closely, while chloride deficit was the largest near the coast, where pollution emission of acidic aerosols were the highest, as evidenced by high submicron mass.

In midday, the $\mathrm{SO}_{2}$ production rate from DMS peaked at 7.5 9.7 $\mu$ moles $\mathrm{m}^{-2} \mathrm{day}^{-1}$, or $6.1 \sim 7.8 \mathrm{pptv} \mathrm{h}^{-1}$.

\subsection{4 $\mathrm{SO}_{2}$ gas phase oxidation}

The rate of daytime oxidation of $\mathrm{SO}_{2}$ by $\mathrm{OH}$ is:

$\left\langle L_{\mathrm{SO}_{2}, \mathrm{OH}}\right\rangle=k_{\mathrm{OH}+\mathrm{SO}_{2}}[\mathrm{OH}]\left\langle\overline{\mathrm{SO}_{2}}\right\rangle$

The second order rate constant between $\mathrm{OH}$ and $\mathrm{SO}_{2}$, $k_{\mathrm{OH}+\mathrm{SO}_{2}}$, is about $9.6 \times 10^{-13} \mathrm{~cm}^{3} \mathrm{molec}^{-1} \mathrm{~s}^{-1}$ at $\sim 13^{\circ} \mathrm{C}$ (Sander et al., 2006). At a $\mathrm{SO}_{2}$ concentration of $35 \mathrm{pptv}$, the diel loss rate was $0.22 \mu$ moles $\mathrm{m}^{-2} \mathrm{day}^{-1}$, or $0.17 \mathrm{pptv} \mathrm{h}^{-1}$. The greatest $\mathrm{SO}_{2}$ loss occurred at a rate of $0.9 \mu_{\text {moles }} \mathrm{m}^{-2} \mathrm{day}^{-1}$, or $0.7 \mathrm{pptv} \mathrm{h}^{-1}$, not in midday, but in the late afternoon.

\subsection{5 $\mathrm{SO}_{2}$ aqueous phase oxidation - in cloud}

With extensive cloud coverage in the SEP, in-cloud oxidation is expected to be a major sink for $\mathrm{SO}_{2}$ and source of $\mathrm{SO}_{4}^{2-}$. Figure 11 shows $\mathrm{SO}_{2}$ concentration below $Z_{\mathrm{i}}$ vs. $L_{\mathrm{WC}}$ for the offshore region. Compared to the concentration below or outside of clouds (which was higher during the day than at night), the interstitial $\mathrm{SO}_{2}$ concentration was reduced to $\sim 18$ pptv. In an aqueous solution, $\mathrm{SO}_{2}$ is equilibrated to $\mathrm{SO}_{2} \cdot \mathrm{H}_{2} \mathrm{O}, \mathrm{HSO}_{3}^{-}$, and $\mathrm{SO}_{3}^{2-}$ :

$\left[\mathrm{SO}_{2} \cdot \mathrm{H}_{2} \mathrm{O}\right]=\mathrm{H}_{\mathrm{SO}_{2}}\left[\mathrm{SO}_{2}\right]$

$\left[\mathrm{HSO}_{3}^{-}\right]=\frac{K_{\mathrm{s} 1}\left[\mathrm{SO}_{2} \cdot \mathrm{H}_{2} \mathrm{O}\right]}{\left[\mathrm{H}^{+}\right]}=\frac{H_{\mathrm{SO}_{2}} K_{\mathrm{s} 1}\left[\mathrm{SO}_{2}\right]}{\left[\mathrm{H}^{+}\right]}$

$\left[\mathrm{SO}_{3}{ }^{2-}\right]=\frac{K_{\mathrm{s} 2}\left[\mathrm{HSO}_{3}^{-}\right]}{\left[\mathrm{H}^{+}\right]}=\frac{\mathrm{H}_{\mathrm{SO}_{2}} K_{\mathrm{s} 1} K_{\mathrm{S} 2}\left[\mathrm{SO}_{2}\right]}{\left[\mathrm{H}^{+}\right]^{2}}$ 


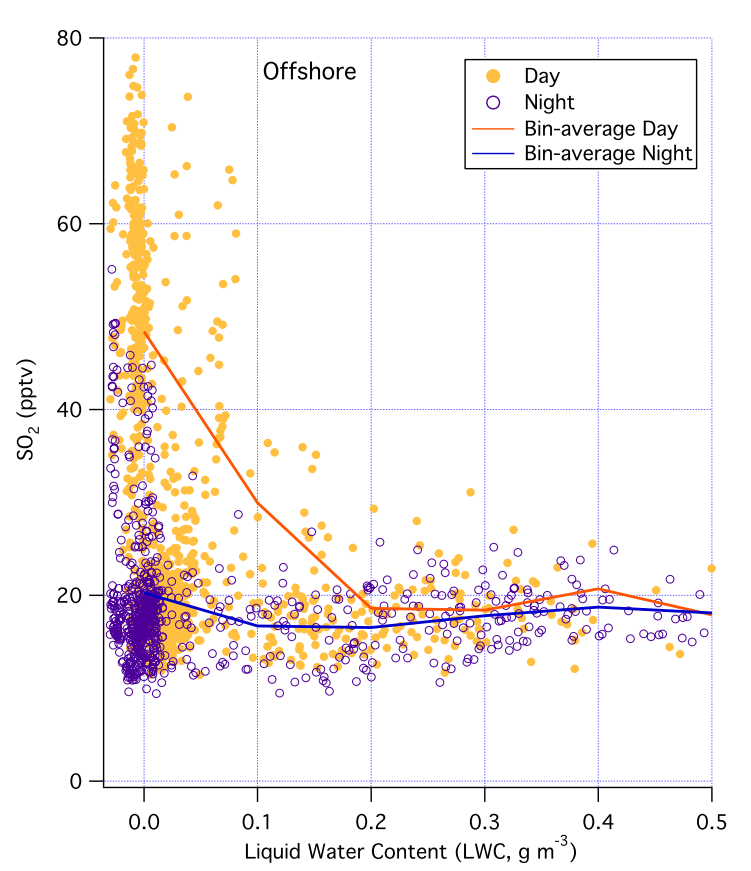

Fig. 11. $\mathrm{SO}_{2}$ concentration below the inversion vs. liquid water content from the $\mathrm{C}-130$ for the VOCAL offshore region, stratified to daytime and nighttime. Higher $\mathrm{SO}_{2}$ during the day was due to DMS oxidation. Above $0.2 \mathrm{~g} \mathrm{~m}^{-3}$ (mean $L_{\mathrm{WC}}$ for the stratocumulus clouds), $\mathrm{SO}_{2}$ was reduced to $\sim 18$ pptv as a result of in-cloud oxidation.

The Henry's coefficient $H_{\mathrm{SO}_{2}}=1.23 \mathrm{M} \mathrm{atm}^{-1}$, equilibrium constants $K_{\mathrm{s} 1}=1.3 \times 10^{-2} \mathrm{M}$, and $K_{\mathrm{s} 2}=6.6 \times 10^{-8} \mathrm{M}$ at $298 \mathrm{~K}$ all increase at lower temperatures with $-\Delta H / R$ of 3135,1960 , and $1495 \mathrm{~K}$, respectively (Hoffmann and Calvert, 1985). Here $\Delta H$ is the change in enthalpy and $R$ is the gas constant. $K$ at the ambient temperature is related to that at $298 \mathrm{~K}\left(K_{298}\right)$ by the relationship $K=$ $\left.K_{298} \exp [-\Delta H / R(1 / T-1 / 298)]\right)$.

In the remote region, with an average cloud water $\mathrm{H}_{2} \mathrm{O}_{2}$ concentration of $65 \mu \mathrm{M}$, or $\sim 0.9 \mathrm{ppbv}$ in the gas phase (Benedict et al., 2011), stoichiometrically there was enough oxidant to oxidize all of the $\mathrm{S}(\mathrm{IV})$ to $\mathrm{SO}_{4}^{2-}$. Bulk cloud water measurements showed mean $\mathrm{SO}_{4}^{2-}$ concentration of $\sim 45 \mu \mathrm{M}$ in the remote region (Benedict et al., 2011), which at $L_{\mathrm{WC}} \approx$ $0.2 \mathrm{~g} \mathrm{~m}^{-3}$ converts to $\sim 200 \mathrm{pptv}$, approximately twice the below cloud concentration. S(IV), on the other hand, was barely detectable in cloud water. Cloud water had an average pH of 4.2 (Benedict et al., 2011), consistent with the ensemble mean $\mathrm{pH}$ of 4.3 in stratocumulus droplets from a recent survey of measurements over the last twenty years (Faloona, 2009). At this $\mathrm{pH}, \mathrm{HSO}_{3}^{-}$is the predominant $\mathrm{S}(\mathrm{IV}$ ) species.

The chemical loss rate of S(IV), and hence the production rate of $\mathrm{SO}_{4}^{2-}$, by reaction with $\mathrm{H}_{2} \mathrm{O}_{2}$ can be estimated according to Martin and Damschen (1981) $\left[\mathrm{M} \mathrm{s}^{-1}\right]$ :

$-\frac{d[\mathrm{~S}(\mathrm{IV})]_{\mathrm{H}_{2} \mathrm{O}_{2}}}{d t}=k_{\mathrm{H}_{2} \mathrm{O}_{2}}\left[\mathrm{H}^{+}\right]\left[\mathrm{H}_{2} \mathrm{O}_{2}\right]\left[\mathrm{HSO}_{3}^{-}\right]$

$$
k_{\mathrm{H}_{2} \mathrm{O}_{2}}=\frac{2.1 \times 10^{6}}{0.1+\left[\mathrm{H}^{+}\right]}
$$

The rate constant $k_{\mathrm{H}_{2} \mathrm{O}_{2}}\left[\mathrm{M}^{-2} \mathrm{~s}^{-1}\right]$ decreases at lower temperatures with $-\Delta H / R=-3650$ (Maahs, 1983). The reaction is largely $\mathrm{pH}$ insensitive because $\left[\mathrm{H}^{+}\right]$in Eqs. (8) and (10) cancel. At a gas phase $\mathrm{SO}_{2}$ concentration of $25 \mathrm{pptv}$, cloud water $\mathrm{H}_{2} \mathrm{O}_{2}$ concentration of $65 \mu \mathrm{M}(0.9 \mathrm{ppbv})$, and $\mathrm{pH}$ of 4.2, the instantaneous loss rate of $\mathrm{S}(\mathrm{IV})$ due to $\mathrm{H}_{2} \mathrm{O}_{2}$ is $7.2 \times 10^{-10} \mathrm{M} \mathrm{s}^{-1}$. An alternate reaction rate by Hoffmann and Calvert (1985) is about three times higher than the one from Martin and Damschen (1981). We demonstrate later that this alternate rate appears to be unrealistically high from the perspective of the steady state mass balance of $\mathrm{SO}_{2}$.

The loss rate of $\mathrm{S}(\mathrm{IV})$ by reaction with $\mathrm{O}_{3}\left[\mathrm{M} \mathrm{s}^{-1}\right]$ is:

$$
\begin{aligned}
-\frac{d[\mathrm{~S}(\mathrm{IV})]_{\mathrm{O}_{3}}}{d t}= & \left(k_{\mathrm{O}_{3,0}}\left[\mathrm{SO}_{2} \cdot \mathrm{H}_{2} \mathrm{O}\right]+k_{\mathrm{O}_{3,1}}\left[\mathrm{HSO}_{3}^{-}\right]\right. \\
& \left.+k_{\mathrm{O}_{3,2}}\left[\mathrm{SO}_{3}^{2-}\right]\right)\left[\mathrm{O}_{3}\right]
\end{aligned}
$$

where $k_{\mathrm{O}_{3}, 0}, k_{\mathrm{O}_{3}, 1}$, and $k_{\mathrm{O}_{3}, 2}$ are $2.4 \times 10^{4}, 3.7 \times 10^{5}$, and $1.5 \times 10^{9} \mathrm{M}^{-1} \mathrm{~s}^{-1}$ at $298 \mathrm{~K}$, respectively (Hoffmann and Calvert, 1985). Because $k_{\mathrm{O}_{3}, 2}$ is orders of magnitude higher than the other two reactions, the overall reaction rate approximately varies inversely with the square of $\left[\mathrm{H}^{+}\right]$and is greatly enhanced at high $\mathrm{pH}$ when there is more $\mathrm{SO}_{3}^{2-}$. At the average cloud $\mathrm{pH}$ and gas phase $\mathrm{O}_{3}$ concentration of $26 \mathrm{ppbv}$, the instantaneous loss rate of $\mathrm{S}(\mathrm{IV})$ due to $\mathrm{O}_{3}$ is $\sim 4 \times 10^{-12} \mathrm{M} \mathrm{s}^{-1}$, two orders of magnitude slower than the $\mathrm{H}_{2} \mathrm{O}_{2}$ reaction. Benedict et al. (2011) examined rates of aqueous $\mathrm{S}\left(\mathrm{IV}\right.$ ) oxidation by $\mathrm{H}_{2} \mathrm{O}_{2}$, by $\mathrm{O}_{3}$, and by $\mathrm{O}_{2}$ (catalyzed by $\mathrm{Fe}$ and $\mathrm{Mn}$ ) and found that $\mathrm{H}_{2} \mathrm{O}_{2}$ was the dominant oxidant in most cases, except where $\mathrm{pH}$ exceeded approximately 5.5 .

The aqueous phase oxidation rate of S(IV) in cloud $\left[\mathrm{M} \mathrm{s}^{-1}\right]$ can be converted to an equivalent gas phase rate of $\mathrm{SO}_{2}$ loss $\left[\mathrm{pptvh}{ }^{-1}\right.$ ] using $L_{\mathrm{WC}}$ :

$$
\begin{aligned}
L_{\mathrm{SO}_{2}, \text { cloud }} & =3.6 \times 10^{9} L_{\mathrm{WC}} R T \\
& \left(-\frac{d[\mathrm{~S}(\mathrm{IV})]_{\mathrm{H}_{2} \mathrm{O}_{2}}}{d t}-\frac{d[\mathrm{~S}(\mathrm{IV})]_{\mathrm{O}_{3}}}{d t}\right)
\end{aligned}
$$

The gas constant $R$ is 0.082 atm $\mathrm{L} \mathrm{K}^{-1}$ mole $^{-1}$; $T$ is the average cloud temperature at $282 \mathrm{~K}$. Under the scenario above,

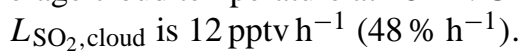

However, using the instantaneous $d[\mathrm{~S}(\mathrm{IV})] / d t$ (i.e. assuming an open system) to budget $\mathrm{SO}_{2}$ loss over time will certainly lead to an overestimation. In a more realistic closed system, without replenishment, the concentration of the limiting reactant decreases significantly as reaction proceeds, and so will $d[\mathrm{~S}(\mathrm{IV})] / d t$. To calculate $\mathrm{SO}_{2}$ depletion as a function of time in cloud, we start initially with $25 \mathrm{pptv}$ of $\mathrm{SO}_{2}, 0.9 \mathrm{ppbv}$ of $\mathrm{H}_{2} \mathrm{O}_{2}, L_{\mathrm{WC}}$ of $0.2 \mathrm{~g} \mathrm{~m}^{-3}$, and $T$ of $282 \mathrm{~K}$. For simplicity, since there is more than sufficient $\mathrm{H}_{2} \mathrm{O}_{2}$ to oxidize all of the $\mathrm{SO}_{2}$ and this reaction is largely 
pH-independent, a constant $\mathrm{pH}$ of 4.2 and an $\mathrm{O}_{3}$ concentration of zero are applied. We also assume rapid equilibration between the gas phase and aqueous phase (i.e. no mass transfer limitation). In this scenario, $9.3 \mathrm{pptv}(37 \%)$ of $\mathrm{SO}_{2}$ is consumed after an hour in cloud, which is 0.8 times the rate calculated from the open system.

From large eddy simulations (LES), Feingold et al. (1998) showed that for a stratocumulus capped MBL, a parcel of air is in clouds for on average $\sim 15 \mathrm{~min}$ in an hour. In the closed system, we calculate $2.8 \mathrm{pptv}$ of $\mathrm{SO}_{2}(\sim 11 \%)$ oxidized to $\mathrm{SO}_{4}^{2-}$ after $15 \mathrm{~min}$, or $1.9 \mathrm{pptv}$ if we account for the mean cloud fraction of $\sim 0.67$. The $\mathrm{SO}_{2}$ formation rate from DMS is $1.8 \sim 2.3 \mathrm{pptv}^{-1}$ (for $\gamma$ of $0.7 \sim 0.9$ ) on a diel average. Adding $\sim 0.1 \mathrm{pptv}^{-1}$ due to entrainment and subtracting dry deposition at $0.4 \mathrm{pptv} \mathrm{h}^{-1}$ and $\mathrm{OH}$ loss at $\sim 0.2 \mathrm{pptv} \mathrm{h}^{-1}$ leaves a daily residual of $1.3 \sim 1.8 \mathrm{pptv} \mathrm{h}^{-1}$. Thus the approximated loss rate of $\mathrm{SO}_{2}$ in clouds appears comparable to the production rate. If using the much higher rate constant of the $\mathrm{SO}_{2}-\mathrm{H}_{2} \mathrm{O}_{2}$ reaction from Hoffmann and Calvert (1985) instead, the in-cloud oxidation of $\mathrm{SO}_{2}$ would far exceed the production from DMS. While the rate constant from Martin and Damschen (1981) appears to be more applicable for VOCALS-REx, the large discrepancy in this reaction rate contributes to the uncertainty of our budget estimates.

In addition, ignoring mass transfer and using mean bulk cloud water parameters may contribute to caveats in the calculations above. Mass transfer from interstitial air to a cloud droplet involves diffusion in the gas phase, interfacial transfer from the gas to the aqueous phase, and diffusion in the aqueous phase. If the rate of the chemical reaction is faster than any of those steps, a gradient in concentration develops away from the interface and the reaction becomes limited by mass transfer. The typical mean cloud droplet radius was $10 \sim 15 \mu \mathrm{m}$ in the VOCALS-REx remote region from satellite imagery. Schwartz (1988) showed that even for $30 \mu \mathrm{m}$ diameter cloud droplets, in-cloud reaction between $\mathrm{SO}_{2}$ and $\mathrm{H}_{2} \mathrm{O}_{2}$ does not appear to be limited by mass transfer. However, both the temperature and the cloud droplet size change significantly during the cloud lifetime. Thus calculations assuming instantaneous equilibrium between the gas and aqueous phase and overly simplified physical conditions should be considered rough estimates.

From this exercise, it appears that in-cloud oxidation was enough to account for essentially all of the $\mathrm{SO}_{2}$ loss, which would render other sinks insignificant. Nevertheless, we will look at the oxidation of $\mathrm{SO}_{2}$ in sea-salt aerosols for the sake of completeness.

\subsection{6 $\mathrm{SO}_{2}$ aqueous phase oxidation - in sea-salt aerosols}

As alluded to previously, the oxidation of $\mathrm{SO}_{2}$ by $\mathrm{O}_{3}$ only becomes important at $\mathrm{pH}>\sim 5.5$. While aerosol $\mathrm{pH}$ was not directly measured during VOCALS-REx, we can get a sense for the acidity of the aerosol phase by looking at filter measurements on the RHB. From ion balance of aerosols, the anion:cation molar equivalent ratio averaged 1.38:1 for the fine mode away from shore, implying acidic aerosols. As $60 \sim 70 \%$ of the total aerosol surface area near the ocean surface was submicron, the fine mode was acidic due to the uptake of $\mathrm{SO}_{2}, \mathrm{SO}_{4}^{2-}$, etc. The anion:cation ratio peaked above 2.3:1 (most acidic) when the ship was near shore, where $\mathrm{SO}_{4}^{2-}$ and $\mathrm{NO}_{3}^{-}$levels from pollution were elevated. This longitudinal pattern anion:cation ratio is in agreement with shipboard AMS measurements of submicron $\mathrm{SO}_{4}^{2-}$ and $\mathrm{NH}_{4}^{+}$ (Fig. 12). $\mathrm{SO}_{4}^{2-}$ in aerosols is typically titrated by ammonium $\left(\mathrm{NH}_{4}^{+}\right)$, which can have continental and marine sources (Zhuang and Huebert, 1996), to form ammonium bisulfate $\left(\mathrm{NH}_{4} \mathrm{HSO}_{4}\right)$ and ammonium sulfate $\left(\left(\mathrm{NH}_{4}\right)_{2} \mathrm{SO}_{4}\right)$, depending on the extent of neutralization. Beyond $\sim 80^{\circ} \mathrm{W}$, the $\mathrm{SO}_{4}^{2}: \mathrm{NH}_{4}^{+}$molar ratio approached the full neutralization limit of $1: 2$ for $\left(\mathrm{NH}_{4}\right)_{2} \mathrm{SO}_{4}$, whereas near shore, $\mathrm{SO}_{4}^{2}: \mathrm{NH}_{4}^{+}$greatly exceeded 1:1 (that of $\mathrm{NH}_{4} \mathrm{HSO}_{4}$ ).

In the coarse mode, the anion:cation ratio averaged 1.03:1 away from shore, less acidic than in the fine mode. A coarse mode with $\mathrm{pH}$ less than 7 can be inferred from observations of chloride deficit, which are included in Fig. 10. Sulfuric and nitric acid vapors react with sea-salt aerosols that are initially rich in sodium chloride, forming hydrochloric acid, which is vaporized to the atmosphere and results in increased acidity and reduced $\mathrm{Cl}^{-}$in reacted sea-salt (e.g. Keene et al., 1990; McInnes et al., 1994). In the offshore region, a small $\mathrm{Cl}^{-}$deficit of $-0.1 \mu \mathrm{g} \mathrm{m}^{-3}$ was observed in the coarse mode. A greater deficit of $-0.9 \mu \mathrm{g} \mathrm{m}^{-3}$ was seen near shore again because of pollution, as evidenced by the much higher submicron aerosol mass. With low aerosol calcium throughout the entire project $\left(0.1 \mu \mathrm{g} \mathrm{m}^{-3}\right)$, the less acidic coarse mode offshore than near the coast was due to the lower uptake of acidic species rather than a titration with alkaline dust materials.

We estimate the order of magnitude sea-salt oxidation rate of $\mathrm{SO}_{2}$ in an analogous fashion to in-cloud oxidation (Eq. 13), but replace $L_{\mathrm{WC}}$ with the integrated supermicron aerosol mass concentration derived from the $\mathrm{RHB}$ size distribution, which averaged $\sim 8 \mu \mathrm{g} \mathrm{m}^{-3}$. At a pH of 6.0 , the $\mathrm{SO}_{2}$ reaction with $\mathrm{O}_{3}$ is two orders of magnitude faster than the reaction with $\mathrm{H}_{2} \mathrm{O}_{2}$. With gas phase $\mathrm{O}_{3}$ and $\mathrm{SO}_{2}$ concentrations of $26 \mathrm{ppbv}$ and $25 \mathrm{pptv}$, respectively, the instantaneous loss rate of $\mathrm{S}(\mathrm{IV})$ due to $\mathrm{O}_{3}$ is $\sim 1.2 \times 10^{-8} \mathrm{M} \mathrm{s}^{-1}$, implying a sea-salt $\mathrm{SO}_{2}$ oxidation rate less than $0.01 \mathrm{pptv} \mathrm{h}^{-1}$, negligible compared to other rates. At a $\mathrm{pH}$ of 6.5 , the oxidation rate of $\mathrm{SO}_{2}$ in sea-salt is increased to $0.08 \mathrm{pptv} \mathrm{h}^{-1}$, but still less than half of the gas phase oxidation rate. By assuming the entire sea-salt volume was reactive and keeping the $\mathrm{pH}$ constant, the calculation above represents an upper level estimate because in real sea-salt aerosols, $\mathrm{SO}_{4}^{2-}$ production and uptake of $\mathrm{SO}_{2}$ by diffusion would acidify the aerosols eventually even with the carbonate buffer, further slowing the $\mathrm{O}_{3}$ reaction. The insignificance of $\mathrm{O}_{3}$ oxidation in the $\mathrm{MBL} \mathrm{SO} \mathrm{S}_{2}$ budget is consistent with the observation that only 


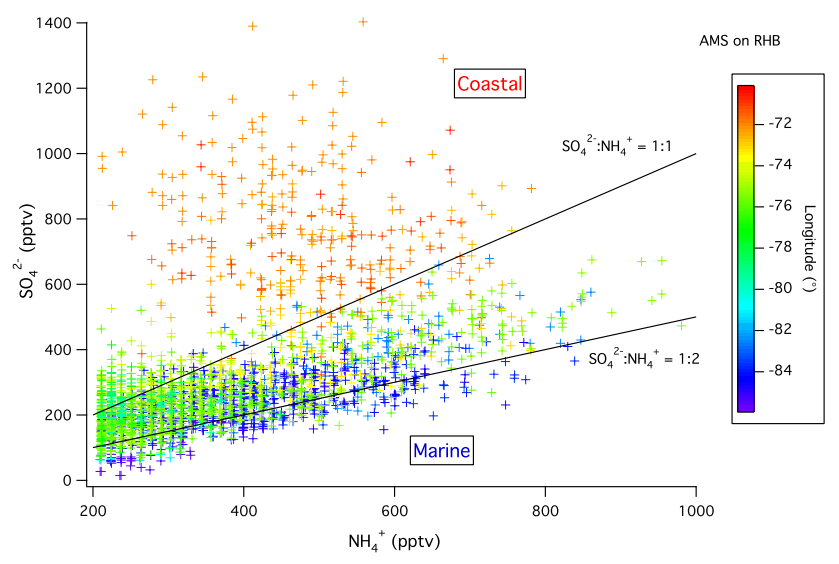

Fig. 12. $\mathrm{SO}_{4}^{2-}$ vs. $\mathrm{NH}_{4}^{+}$from the shipboard AMS, color-coded by longitude. The $\mathrm{SO}_{4}^{2-}: \mathrm{NH}_{4}^{+}$ratio approached the theoretical full neutralization limit of 1:2 for ammonium sulfate in the remote marine region. Closer to shore, the ratio exceeded 1:1 (that of ammonium bisulfate) due to pollution emission.

$5 \sim 6 \%$ of the total non-sea-salt $\mathrm{SO}_{4}^{2-}$ was found in the coarse mode during VOCALS-REx per filter measurements. Moreover, this percentage was relatively insensitive to longitude, whereas the $\mathrm{pH}$ of sea-salt aerosols likely differed substantially from near shore to the remote marine region, suggesting that mechanisms other than $\mathrm{O}_{3}$ oxidation (e.g. direct uptake of $\mathrm{H}_{2} \mathrm{SO}_{4}$, in-cloud oxidation by $\mathrm{H}_{2} \mathrm{O}_{2}$, and evaporation following wet scavenging) were responsible for $\mathrm{SO}_{4}^{2-}$ to be present in the coarse mode.

\subsection{7 $\mathrm{SO}_{2}$ budget summary}

To more accurately calculate the sources and sinks of $\mathrm{SO}_{2}$, we look at their time-evolutions over the course of a day and compare the implied $\mathrm{SO}_{2}$ diurnal cycle with observations. From Eq. (2), omitting sea-salt oxidation, the column integrated concentration of $\mathrm{SO}_{2}$ at time $t$ can be written as:

$$
\begin{aligned}
\left\langle\overline{\mathrm{SO}}_{2}\right\rangle_{t} & =\left\langle\overline{\mathrm{SO}_{2}}\right\rangle_{t-1}+\left(F_{\mathrm{SO}_{2}, 0}\right)_{t-1}-\left(F_{\mathrm{SO}_{2}, Z_{\mathrm{i}}}\right)_{t-1} \\
& +\left\langle P_{\mathrm{SO}_{2}}\right\rangle_{t-1}-\left\langle L_{\mathrm{SO}_{2}, \mathrm{OH}}\right\rangle_{t-1}-\left\langle L_{\mathrm{SO}_{2}, \text { cloud }}\right\rangle_{t-1}
\end{aligned}
$$

The last five terms on the RHS represent time-integrated rates since the previous time step. C-130 Observations of $\mathrm{SO}_{2}$ in the remote region were available in the hours of 08:00 20:00 UTC. We initialize our calculation with the mean observation at 09:00 UTC (06:00 a.m. local) because that was approximately the time when the aircraft reached the westernmost location $\left(80 \sim 85^{\circ} \mathrm{W}\right)$ on most $20^{\circ} \mathrm{S}$ survey flights. Measurements in the following few hours should be subject to the least amount of spatial and temporal bias. Before 09:00 and after 15:00 UTC, the aircraft was closer to the coast and could be on either the outbound (pre-dawn) or the return leg (later morning to afternoon). Implied DMS and $\mathrm{OH}$ concentrations are derived from the DMS budget (Yang et al., 2009) for the remote region and used to estimate $\mathrm{SO}_{2}$ production assuming conversion efficiencies of 0.7 and 0.9 from DMS to $\mathrm{SO}_{2}$. Implied DMS agrees with DMS observation from the ship (Fig. 8) very well on a diel basis. Over $24 \mathrm{~h}$, we consider the budget closed when the concentration at the end of the calculation matches that at the beginning under the assumptions of steady state and stationarity.

From direct measurements of DMS, $\mathrm{O}_{3}$, and water vapor fluxes, Faloona et al. (2005) found higher $\omega_{\mathrm{e}}$ at night in the stratocumulus region off the coast of California due to greater radiatively driven turbulence and cloud coverage than during the day, qualitatively consistent with diurnal estimates from Caldwell et al. (2005) in the SEP using a mixed layer budget approach. Based on the role of clouds in entrainment, we roughly approximate the diel variability in $\omega_{\mathrm{e}}$ for VOCALS-REx by linearizing the mean $\omega_{\mathrm{e}}=4 \mathrm{~mm} \mathrm{~s}^{-1}$ with cloud fraction at each hour relative to the mean cloud fraction (0.67), which leads to a maximum of $6 \mathrm{~mm} \mathrm{~s}^{-1}$ at night and minimum of $2 \mathrm{~mm} \mathrm{~s}^{-1}$ during the day. As seen in Fig. 13, entrainment, deposition, and gas phase $\mathrm{OH}$ oxidation are all minor losses of $\mathrm{SO}_{2}$. In-cloud oxidation, the largest sink for $\mathrm{SO}_{2}$, is estimated using a fixed $\mathrm{H}_{2} \mathrm{O}_{2}$ concentration of $0.9 \mathrm{ppbv}$ and constant $\mathrm{pH}$ of 4.2 (i.e. an open system). The concentration of $\mathrm{SO}_{2}$ below $Z_{\mathrm{i}}$ is adjusted from the implied time dependent $\mathrm{MBL} \mathrm{SO}_{2}$ concentration using the observed gradient from $\mathrm{C}-130$ profiles. The aqueous concentration of $\mathrm{S}(\mathrm{IV})$ is equilibrated with the cloud level $\mathrm{SO}_{2}$. Instead of using $L_{\mathrm{WC}}$ from the C-130 and guessing the time parcels spend in clouds, we use the liquid water path $\left(L_{\mathrm{WP}}\right)$ determined from the ship, which accounted for both cloudy and clear air conditions. For $\gamma=0.9$, we find that the in-cloud oxidation loss term needs to be reduced by half to balance the diel budget of $\mathrm{SO}_{2}$. This factor is necessary probably due to the assumption of an open system and uncertainties in the in-cloud oxidation calculation. As shown in Fig. 13, the implied $\mathrm{SO}_{2}$ cycle matches well with observations until 13:00 UTC (a few hours after sunrise). Comparison worsens for subsequent hours partly due to the large spatial variability and bias of the C-130 observations. Also, $\mathrm{SO}_{2}$ observations in bins at 08:00 and 20:00 UTC have an order of magnitude less number of points than the bins from 09:00 to 13:00. Thus the discrepancy between observed and implied $\mathrm{SO}_{2}$ after 13:00 UTC is also likely related to poor measurement statistics.

\section{2 $\mathrm{SO}_{4}^{2-}$ budget}

From an island-based experiment in the Equatorial Pacific, where the cloud cover is much lower and the decoupling between the surface and $Z_{\mathrm{i}}$ more permanent than in the SEP, Huebert et al. (1996) measured a clear diurnal cycle in $\mathrm{SO}_{4}^{2-}$ aerosols. $\mathrm{SO}_{4}^{2-}$ built up slowly during the day and peaked near sunset, consistent with photochemical production from $\mathrm{SO}_{2}$. Dilution due to entrainment was mostly responsible for the nighttime $\mathrm{SO}_{4}^{2-}$ decline. In contrast to this diel trend, $\mathrm{SO}_{4}^{2-}$ during VOCALS-REx was the lowest in the late after- 


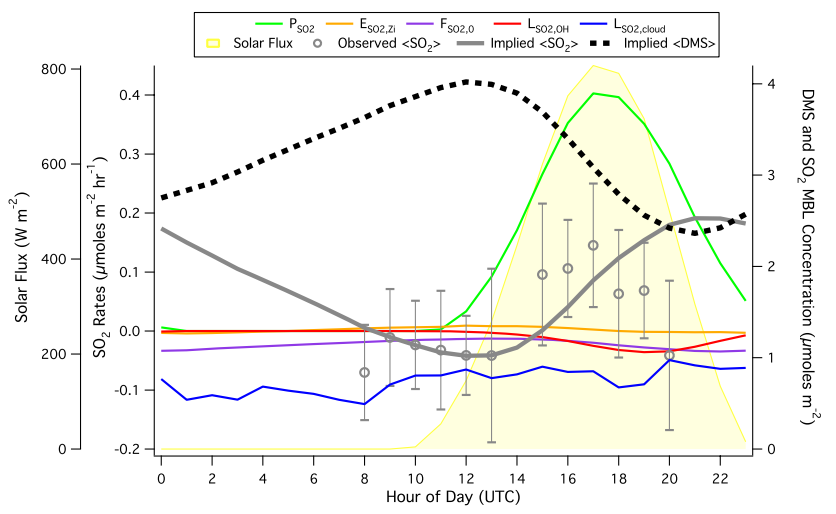

Fig. 13. Implied $\mathrm{SO}_{2}$ diel cycle, with oxidation from DMS being the principal source and in-cloud oxidation as the main sink. The implied $\mathrm{SO}_{2}$ cycle agrees well with observations (gray circles, with error bars corresponding to standard deviation within hour bins) until 15:00 UTC, with measurements before 09:00 UTC and after 15:00 UTC subject to greater spatial/temporal bias as well as poorer sampling statistics.

noon, increased rapidly over the first several hours after sunset, then decreased steadily and leveled off over the rest of the diel cycle. As with $\mathrm{SO}_{2}$, we first look at the magnitudes of the different terms in the $\mathrm{SO}_{4}^{2-}$ budget:

$$
\frac{\partial\left\langle\overline{\mathrm{SO}_{4}^{2-}}\right\rangle}{\partial t}=F_{\mathrm{SO}_{4}^{2-}, 0, \text { dry }}+F_{\mathrm{SO}_{4}^{2-}, 0, \text { wet }}-F_{\mathrm{SO}_{4}^{2-}, Z_{\mathrm{i}}}+\left\langle P_{\mathrm{SO}_{4}^{2-}}\right\rangle
$$

The first three terms on the RHS are dry deposition to the surface, wet deposition due to precipitation, and the combined effect of entrainment and wind divergence, respectively. The last term represents in situ production of $\mathrm{SO}_{4}^{2-}$ from $\mathrm{SO}_{2}$.

\subsection{1 $\mathrm{SO}_{4}^{2-}$ dry deposition}

The surface flux of $\mathrm{SO}_{4}^{2-}$ is related to the concentration at the surface $\left(\left[\mathrm{SO}_{4,0}^{2-}\right]\right)$ :

$F_{\mathrm{SO}_{4}^{2-}, 0, \text { dry }}=-\int_{0}^{\infty} V_{\text {aero }}(D)\left[\mathrm{SO}_{4}^{2-}{ }_{0}(D)\right] d D$

The deposition velocity of particles, $V_{\text {aero }}$, is a strong function of particle size $(D)$. Coarse particles deposit orders of magnitude faster due to gravitational settling than particles in the accumulation mode, where the vast majority of the $\mathrm{SO}_{4}^{2-}$ mass was found. At less than $0.02 \mu \mathrm{g} \mathrm{m}^{-3}$ ( $\left.\sim 5 \mathrm{pptv}\right)$, only $\sim 5 \%$ of the total non-sea-salt $\mathrm{SO}_{4}^{2-}$ was present in the coarse mode away from shore per filter measurements. Lacking size distributed $\mathrm{SO}_{4}^{2-}$ concentrations, we rely on shipboard APS aerosol size distribution and coarse $\mathrm{SO}_{4}^{2-}$ mass from filter measurements to estimate dry deposition flux.

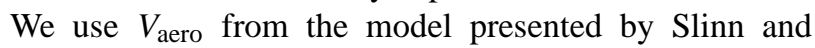
Slinn (1980), with wet diameters adjusted from $60 \% \mathrm{RH}$ to the ambient $\mathrm{RH}$ according to the sea-salt growth curve (Howell et al., 2006). At the upper size cutoff of the APS ( $\sim 11 \mu \mathrm{m}$ at ambient $\mathrm{RH}), V_{\text {aero }}$ peaks at $\sim 0.2 \mathrm{~cm} \mathrm{~s}^{-1}$. Integrating mass distributions over supermicron sizes yields a concentration that agrees well with coarse gravimetric mass from the filters $\left(\sim 8 \mu \mathrm{g} \mathrm{m}^{-3}\right)$, of which $\sim 0.5 \%$ was non-seasalt $\mathrm{SO}_{4}^{2-}$. To approximate size resolved $\mathrm{SO}_{4}^{2-}$, we apply this percentage uniformly to the supermicron mass distribution (i.e. assuming coarse $\mathrm{SO}_{4}^{2-}$ has the same relative distribution as sea-salt aerosols). Previous impactor measurements in the remote Pacific showed that most of the coarse $\mathrm{SO}_{4}^{2-}$ is present at $2 \sim 3 \mu \mathrm{m}$, or towards the smaller end of the supermicon spectrum (R. Simpson, personal communication, 2010), whereas the distribution of sea-salt tends to be broader. Allocating more $\mathrm{SO}_{4}^{2-}$ to the larger end of the supermicon spectrum, where the deposition velocity is much higher, could thus overestimate deposition flux.

Multiplying the approximated $\mathrm{SO}_{4}^{2-}$ distribution by $V_{\text {aero }}$ and summing over supermicron sizes leads to a mean surface flux of merely $\sim 0.002 \mu$ moles $\mathrm{m}^{-2} \mathrm{day}^{-1}$. Even with a tenfold higher $V_{\text {aero }}$, the resultant deposition flux would still be only $\sim 10 \%$ of the $\mathrm{SO}_{4}^{2-}$ production rate from the gas phase oxidation of $\mathrm{SO}_{2}$, and orders of magnitude lower than other terms in the $\mathrm{SO}_{4}^{2-}$ budget.

\subsection{2 $\mathrm{SO}_{4}^{2-}$ entrainment}

The entrainment of $\mathrm{SO}_{4}^{2-}$ is calculated similarly to that of $\mathrm{SO}_{2}$ (Eq. 4). From average $\mathrm{C}-130$ profiles, with a $\mathrm{SO}_{4}^{2-}$ concentration below $Z_{\mathrm{i}} \sim 40$ pptv less than above, entrainment diluted the MBL at a rate of $0.5( \pm 0.3) \mu$ mole $\mathrm{m}^{-2}$ day $^{-1}$, or $0.4( \pm 0.2) \mathrm{pptv} \mathrm{h}^{-1}$. The $20 \sim 30 \mathrm{pptv}$ of $\mathrm{SO}_{4}^{2-}$ observed at cloud level was biased towards clear sky, cloud outflow, and POC regions, thus not representative of the concentration below $Z_{\mathrm{i}}$.

\subsection{3 $\mathrm{SO}_{4}^{2-}$ production}

The in situ production rate of $\mathrm{SO}_{4}^{2-}$ is approximately equal to losses of $\mathrm{SO}_{2}$ in both the gas phase and aqueous phase:

$\left\langle P_{\mathrm{SO}_{4}^{2-}}\right\rangle=\left\langle P_{\mathrm{SO}_{4}^{2-}, \mathrm{OH}}\right\rangle+\left\langle P_{\mathrm{SO}_{4}^{2-}, \text { cloud }}\right\rangle$

Based on the estimated cloud level concentration of $\mathrm{SO}_{2}$, we calculated an in-cloud $\mathrm{SO}_{4}^{2-}$ production of $4 \mu$ moles $\mathrm{m}^{-2}$ over $24 \mathrm{~h}$. This rate (equivalent to $80 \mathrm{pptv}^{\mathrm{day}}{ }^{-1}$ ) is similar to what was reported by Huebert et al. (1996) and Clarke et al. (1996) over the Equatorial Pacific.

\subsection{4 $\mathrm{SO}_{4}^{2-}$ wet deposition}

Because of its high water solubility, $\mathrm{SO}_{4}^{2-}$ is readily taken up in clouds. Coalescence of cloud droplets form precipitation, which removes aerosols both scavenged in-cloud and collected in the column of air below while falling. Figure 14 


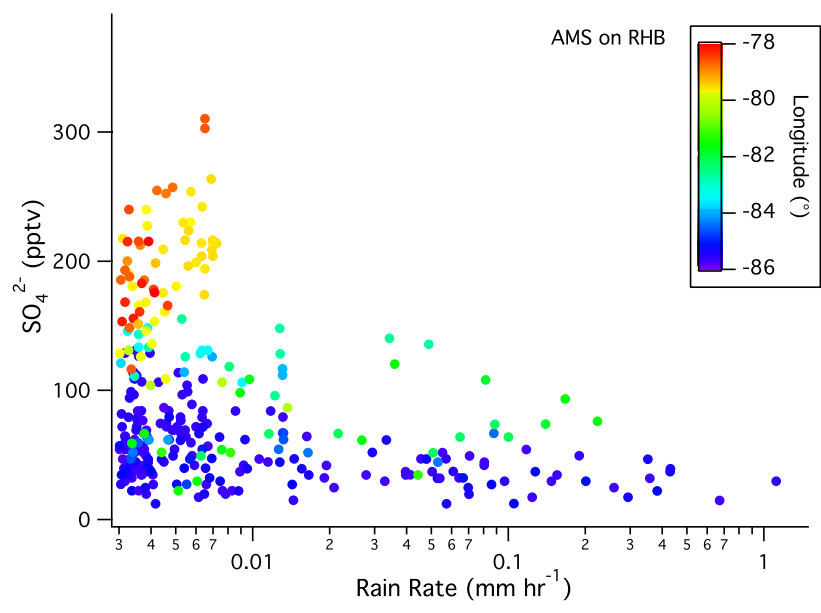

Fig. 14. $R H B \mathrm{SO}_{4}^{2-}$ concentration vs. rain rate, color-coded by longitude. While there was clearly a longitudinal trend in $\mathrm{SO}_{4}^{2-}$, the lowest concentration at $85^{\circ} \mathrm{W}$ corresponded to high rain rates, suggesting efficient precipitation scavenging.

shows $\mathrm{SO}_{4}^{2-}$ vs. rain rate reaching the surface $\left(P_{\mathrm{d}}\right)$ measured by the shipboard rain gauge, color-coded by longitude. The heaviest precipitation events $\left(>1 \mathrm{~mm} \mathrm{~h}^{-1}\right)$ occurred west of $80^{\circ} \mathrm{W}$ and were associated with the lowest $\mathrm{SO}_{4}^{2-}$. The average $P_{\mathrm{d}}$ of $0.01 \mathrm{~mm} \mathrm{~h}^{-1}$ in the remote region (including non-precipitating periods) is consistent with the typical cloud base drizzle rate of $1 \sim 2 \mathrm{~mm} \mathrm{day}^{-1}$ derived from C-130 radar and lidar measurements, with 10 20\% reaching the surface (Bretherton et al., 2010).

The wet deposition flux of $\mathrm{SO}_{4}^{2-}$ is the sum of below cloud scavenging $\left(F_{\mathrm{SO}_{4}^{2-}, 0, \mathrm{BC}}\right)$ and in-cloud scavenging $\left(F_{\mathrm{SO}_{4}^{2-}, 0, \mathrm{IC}}\right)$. The below cloud scavenging rate of $\mathrm{SO}_{4}^{2-}$ by droplets reaching the surface depends on the mean MBL concentration:

$F_{\mathrm{SO}_{4}^{2-}, 0, \mathrm{BC}}=-\Lambda_{\mathrm{BC}}\left[\mathrm{SO}_{4}^{2-}\right] \mathrm{H}_{\mathrm{BC}}$

Here $\Lambda_{\mathrm{BC}}$ is the below cloud scavenging coefficient of $\mathrm{SO}_{4}^{2-}$, which is a function of rain rate and the collection efficiency. Andronache (2003) showed that small drizzle droplets are more efficient at scavenging aerosols than larger rain droplets. Scavenging by falling droplets is particularly efficient for coarse particles (by impaction) and for nuclei mode particles (by Brownian motion). In contrast, accumulation size particles lie in the "scavenging well" and have the lowest efficiency. From Seinfeld and Pandis (2006), for typical drizzle diameter of $0.2 \mathrm{~mm}$ and $200 \sim 300 \mathrm{~nm}$ aerosols (mean diameter for $\mathrm{SO}_{4}^{2-}$ mass during VOCALS-Rex), $\Lambda_{\mathrm{BC}}$ is about $0.01 \mathrm{~h}^{-1}$ for a rain rate of $1 \mathrm{~mm} \mathrm{~h}^{-1}$. We estimate $\Lambda_{\mathrm{BC}}\left[\mathrm{h}^{-1}\right]$ as $0.01\left(P_{\mathrm{d}} / 1\right)$. For a well-mixed MBL, $H_{\mathrm{BC}}$ is the height from the surface to the bottom of a precipitating cloud, which we approximate with $M L H$. From Eq. (18), we calculate a below cloud
$\mathrm{SO}_{4}^{2-}$ wet removal of $0.006 \mu$ mole $\mathrm{m}^{-2} \mathrm{day}^{-1}$ on average and $\sim 0.1 \mu$ mole $\mathrm{m}^{-2} \mathrm{day}^{-1}$ for heavy rain events.

Most of the wet removal of $\mathrm{SO}_{4}^{2-}$ was due to in-cloud scavenging. When cloud forms in a rising air parcel, $\mathrm{SO}_{4}^{2-}$ aerosols mostly become cloud droplets (nucleation scavenging) and are later removed by precipitation. ten Brink et al. (1986) found very low levels of aerosol $\mathrm{SO}_{4}^{2-}$ in cloud interstitial air compared to cloud-free air, suggesting a high scavenging efficiency at relatively low concentrations by cloud droplets. The in-cloud scavenging of $\mathrm{SO}_{4}^{2-}$ is formulated similarly to below cloud scavenging, but with in-cloud scavenging coefficient $\left(\Lambda_{\mathrm{IC}}\right)$ and concentration integrated to $Z_{\mathrm{i}}$ :

$F_{\mathrm{SO}_{4}^{2-}, 0, \mathrm{IC}}=-\Lambda_{\mathrm{IC}} \overline{\mathrm{SO}_{4}^{2-}}$

Okita et al. (1996) found a bulk scavenging efficiency of $0.5 P_{\mathrm{d}}{ }^{0.74} \mathrm{~h}^{-1}$ from $\mathrm{SO}_{4}^{2-}$ measurements over the Sea of Japan during a winter monsoon. Following theories from Scott (1982) and constrained by bulk precipitation measurements from the Eastern United States, Andronache (2004) parameterized $\Lambda_{\mathrm{IC}}$ of $\mathrm{SO}_{4}^{2-}$ using a Marshall and Palmer (1948) precipitation size distribution: 1.26 $P_{\mathrm{d}}^{0.78} \mathrm{~h}^{-1}$. Utilizing at the moment the parameterization from Okita et al. (1996), the in-cloud scavenging loss would be $\sim 1.2 \mu$ mole $\mathrm{m}^{-2}$ day $^{-1}$ and over $25 \mu$ mole $^{-2}$ day $^{-1}$ for the heaviest precipitation events.

\subsection{5 $\mathrm{SO}_{4}^{2-}$ budget summary}

Assuming a well-mixed MBL and omitting dry deposition, the column integrated concentration of $\mathrm{SO}_{4}^{2-}$ at time $t$ can be written as:

$$
\begin{aligned}
\left\langle\overline{\left.\mathrm{SO}_{4}^{2-}\right\rangle_{t}}\right. & =\left\langle\overline{\mathrm{SO}_{4}^{2-}}\right\rangle_{t-1} \\
& -\left(F_{\mathrm{SO}_{4}^{2-}, Z_{\mathrm{i}}}\right)_{t-1}+\left\langle P_{\mathrm{SO}_{4}^{2-}}\right\rangle_{t-1}-\left\langle F_{\mathrm{SO}_{4}^{2-}, \text { wet }}\right\rangle_{t-1}
\end{aligned}
$$

Shipboard $\mathrm{SO}_{4}^{2-}$ measurements were taken in the remote region during 24 30 October and 16 17 November. We initiate our calculation with the observation at 00:00 UTC and compute over one diel cycle. To quantify the average effect of episodic rainfall, the mean precipitation rate of $0.01 \mathrm{~mm} \mathrm{~h}^{-1}$ is linearized with the relative cloud fraction, as done with $\omega_{\mathrm{e}}$. We found that $\Lambda_{\mathrm{IC}}$ of $1.0 P_{\mathrm{d}}^{0.74} \mathrm{~h}^{-1}$, which is between the parameterizations from Okita et al. (1996) and Andronache (2004), results in a general budget balance. As seen in Fig. 15, being proportional to $L_{\mathrm{WP}}$, the in-cloud oxidation of $\mathrm{SO}_{2}$ peaks in the early morning, which is largely offset by wet deposition that also peaks at the same time when cloud fraction was usually the highest. Without clouds, gas phase oxidation would slowly build up $\mathrm{SO}_{4}^{2-}$ during the day, as in Huebert et al. (1996). However, the processes above do not capture the observed diel trend in VOCALS-REx. 
Table 1. Diel averaged rates in MBL concentration budgets of $\mathrm{DMS}, \mathrm{SO}_{2}$, and $\mathrm{SO}_{4}^{2-}$.

\begin{tabular}{|c|c|c|c|c|c|c|}
\hline DMS & $\mu$ mole $\mathrm{m}^{-2} \mathrm{day}^{-1}$ & $\operatorname{pptv~}^{-1}$ & $\%$ day $^{-1}$ & & & \\
\hline Sea-to-air Flux & $3.81 \pm 0.38$ & $3.09 \pm 0.31$ & $118 \pm 12$ & & & \\
\hline Entrainment & $-0.66 \pm 0.33$ & $-0.54 \pm 0.27$ & $-20 \pm 10$ & & & \\
\hline \multirow[t]{2}{*}{ Loss to $\mathrm{OH}$} & $-3.15 \pm 0.50$ & $-2.56 \pm 0.41$ & $-97 \pm 16$ & & & \\
\hline & $\gamma=0.9$ & & \multicolumn{4}{|c|}{$\gamma=0.7$} \\
\hline $\mathrm{SO}_{2}$ & $\mu$ mole $\mathrm{m}^{-2} \mathrm{day}^{-1}$ & $\operatorname{pptvh}^{-1}$ & $\%$ day $^{-1}$ & $\mu$ mole $\mathrm{m}^{-2}$ day $^{-1}$ & $\mathrm{pptv}^{-1}$ & $\%$ day $^{-1}$ \\
\hline Prod. from DMS & $2.84 \pm 0.45$ & $2.30 \pm 0.37$ & $158 \pm 25$ & $2.21 \pm 0.35$ & $1.79 \pm 0.29$ & $134 \pm 21$ \\
\hline Entrainment & $0.05 \pm 0.02$ & $0.04 \pm 0.02$ & $3 \pm 1$ & $0.06 \pm 0.03$ & $0.05 \pm 0.03$ & $4 \pm 2$ \\
\hline Dry Deposition & $-0.56 \pm 0.14$ & $-0.45 \pm 0.11$ & $-31 \pm 8$ & $-0.51 \pm 0.13$ & $-0.41 \pm 0.10$ & $-31 \pm 8$ \\
\hline Loss to $\mathrm{OH}$ & $-0.22 \pm 0.03$ & $-0.18 \pm 0.02$ & $-12 \pm 2$ & $-0.20 \pm 0.03$ & $-0.16 \pm 0.02$ & $-12 \pm 2$ \\
\hline Loss to Clouds & $-2.10 \pm 0.48$ & $-1.70 \pm 0.39$ & $-117 \pm 26$ & $-1.56 \pm 0.38$ & $-1.27 \pm 0.31$ & $-95 \pm 23$ \\
\hline $\mathrm{SO}_{4}^{2-}$ & $\mu$ mole $\mathrm{m}^{-2}$ day $^{-1}$ & pptv $^{-1}$ & $\%$ day $^{-1}$ & $\mu$ mole $\mathrm{m}^{-2}$ day $^{-1}$ & pptv $^{-1}$ & $\%$ day $^{-1}$ \\
\hline Prod. from $\mathrm{SO}_{2}$ & $4.02 \pm 0.89$ & $3.26 \pm 0.72$ & $75 \pm 16$ & $3.32 \pm 0.70$ & $2.70 \pm 0.57$ & $62 \pm 13$ \\
\hline Entrainment & $-0.51 \pm 0.26$ & $-0.41 \pm 0.21$ & $-9 \pm 5$ & $-0.28 \pm 0.14$ & $-0.23 \pm 0.11$ & $-5 \pm 3$ \\
\hline Wet Deposition & $-3.51 \pm 0.92$ & $-2.85 \pm 0.75$ & $-65 \pm 17$ & $-3.04 \pm 0.72$ & $-2.47 \pm 0.58$ & $-56 \pm 13$ \\
\hline
\end{tabular}

Positive (negative) indicate increases (decreases) in MBL concentrations.

$\mathrm{SO}_{2}$ and $\mathrm{SO}_{4}^{2-}$ rates are calculated with two separate DMS to $\mathrm{SO}_{2}$ conversion efficiencies, 0.9 and 0.7.

Rates in pptv $\mathrm{h}^{-1}$ are calculated using a diel mean MBL height of $1.3 \mathrm{~km}$.

Percent daily rates are calculated with respect to observed (DMS and $\mathrm{SO}_{4}^{2-}$ ) or implied $\left(\mathrm{SO}_{2}\right)$ daily mean concentrations.

Errors for entrainment, dry deposition, and $\mathrm{SO}_{2}$ oxidation are estimated from uncertainty in $\omega_{\mathrm{e}}, V_{\mathrm{dep}}$, and [OH], with errors for other rates propagated under $95 \%$ confidence.

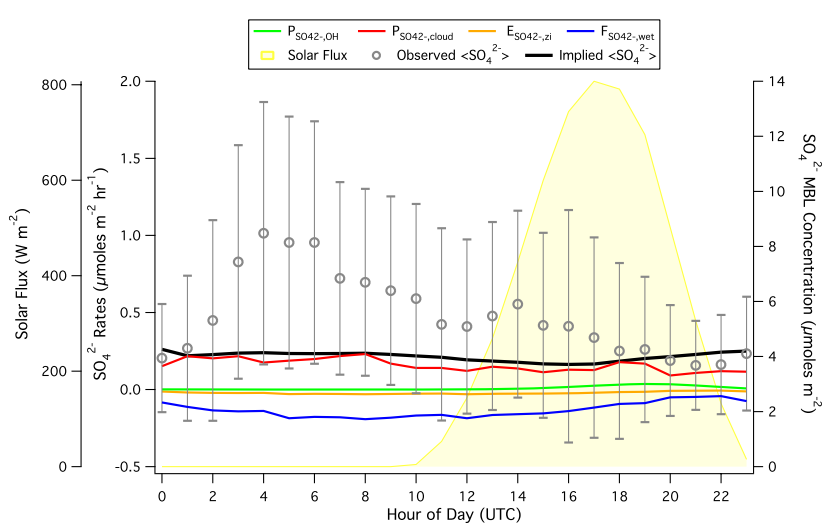

Fig. 15. Implied $\mathrm{SO}_{4}^{2-}$ cycle assuming a well-mixed MBL, with calculation initiated with the observation at 00:00 UTC. The incloud production term is largely offset by wet deposition, with gas phase oxidation by $\mathrm{OH}$ accounting for the small increase in $\mathrm{SO}_{4}^{2-}$ towards the end of the day. While the source and sink terms appear to balance, the observed diel cycle in $\mathrm{SO}_{4}^{2-}$ (gray circles, with error bars corresponding to standard deviation within hour bins) is not captured by this calculation.

That the surface $\mathrm{O}_{3}$ concentration increased along with $\mathrm{SO}_{4}^{2-}$ in the early evening suggests that the main source of $\mathrm{SO}_{4}^{2-}$ spike was from above. High levels of $\mathrm{SO}_{4}^{2-}$ were not usually observed in the remote FT, which left the cloud level to be the more likely source of $\mathrm{SO}_{4}^{2-}$. During the day, due to the decoupling of the $\mathrm{MBL}, \mathrm{SO}_{4}^{2-}$ generated in clouds could be isolated in the upper MBL. The recoupling of the MBL after sunset would mix down this air rich in $\mathrm{SO}_{4}^{2-}$, causing a spike in measured concentration. $\mathrm{SO}_{4}^{2-}$ was then depleted by wet deposition over the rest of diurnal cycle, with the most rapid loss in the early morning. To test this proposed mechanism, instead of adding in-cloud $\mathrm{SO}_{2}$ oxidation to the $\mathrm{SO}_{4}^{2-}$ budget continuously as in Eq. (20), we sum in-cloud $\mathrm{SO}_{2}$ oxidation over $24 \mathrm{~h}$ and incorporate it to $\mathrm{MBL} \mathrm{SO}_{4}^{2-}$ budget only during the first four hours after sunset. The daily production of $\mathrm{SO}_{4}^{2-}$ in cloud amounted to $4 \mu$ moles $\mathrm{m}^{-2}$, similar to the increase observed from 00:00 to 04:00 UTC. Thus we add $1 \mu$ moles $\mathrm{m}^{-2}$ of $\mathrm{SO}_{4}^{2-}$ to each of these four hours and recalculate the $\mathrm{SO}_{4}^{2-}$ budget (Fig. 16). As wet depositional loss is first order, the large amount of $\mathrm{SO}_{4}^{2-}$ added initially is adequately depleted over the rest of the diurnal cycle and the implied diel variability is qualitatively similar to observations.

The major rates in the $\mathrm{MBL} \mathrm{SO}_{2}$ and $\mathrm{SO}_{4}^{2-}$ budgets are shown in Table 1, with both choices of $\gamma$. A refinement to the one layer box model utilized here for our diel calculations would be to solve the upper and lower parts of the MBL separately in the decoupled daytime; at night the two layers would join to become one. However, not knowing the exchange between the upper and lower parts of the MBL during the day makes the implementation of such a dynamical model difficult for the time being. 


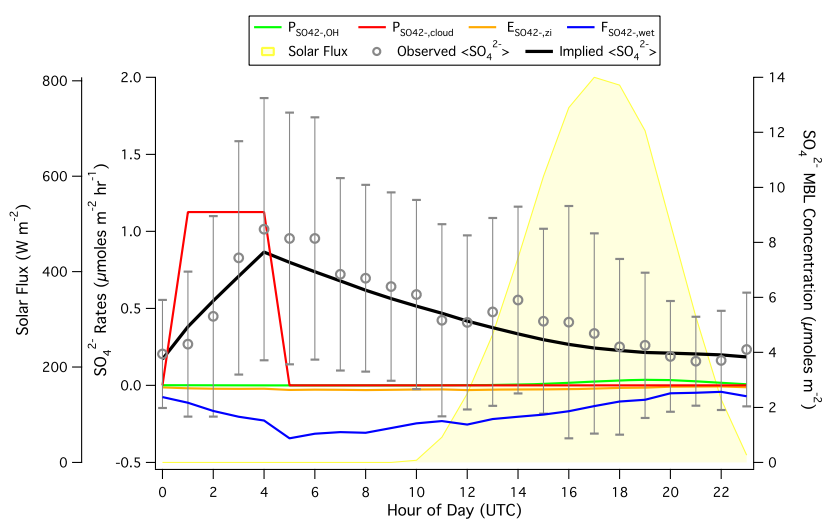

Fig. 16. Implied $\mathrm{SO}_{4}^{2-}$ cycle assuming a well-mixed $\mathrm{MBL}$ at night and decoupled MBL during the day. $\mathrm{SO}_{4}^{2-}$ produced in-cloud is summed over the entire day and only added to the MBL budget over the first four hours after sunset as the MBL recoupled. Initiated with the observation at 00:00 UTC, the implied cycle qualitatively agrees with shipboard observations.

\section{Conclusions}

In order to evaluate the effects of anthropogenic sulfur inputs to the atmosphere, we must first understand the natural background cycles. In VOCALS-REx, multiplatform observations and relatively simple dynamics of the stratocumulus capped marine boundary layer allowed us to estimate the sources and sinks of DMS, $\mathrm{SO}_{2}$, and $\mathrm{SO}_{4}^{2-}$ aerosols. The sea-to-air flux of DMS $\left(3.8 \pm 0.4 \mu\right.$ moles $\mathrm{m}^{-2}$ day $\left.^{-1}\right)$, rather than the entrainment of $\mathrm{SO}_{2}$ and $\mathrm{SO}_{4}^{2-}(0.05 \pm 0.02$ and $-0.5 \pm 0.3 \mu$ moles $\mathrm{m}^{-2} \mathrm{day}^{-1}$ ), was the predominant source of sulfur mass to the remote region of the SEP. Accounting for dilution due to entrainment $\left(0.7 \pm 0.3 \mu\right.$ moles $\left.\mathrm{m}^{-2} \mathrm{day}^{-1}\right)$, the remaining DMS was oxidized by $\mathrm{OH}$ to mostly $\mathrm{SO}_{2}$. At a DMS to $\mathrm{SO}_{2}$ conversion efficiency $(\gamma)$ of $0.7 \sim 0.9$, the $\mathrm{SO}_{2}$ production rate from DMS was about $2.2 \sim 2.8 \mu$ moles $\mathrm{m}^{-2}$ day $^{-1}$, peaking at $7.5 \sim 9.7 \mu$ moles $\mathrm{m}^{-2} \mathrm{day}^{-1}$ in midday. From our implied diel cycle calculations $(\gamma=0.9)$, entrainment slightly increased the MBL $\mathrm{SO}_{2}$ burden at a rate of $0.05 \pm 0.02 \mu$ moles $\mathrm{m}^{-2} \mathrm{day}^{-1}$, while dry deposition decreased $\mathrm{SO}_{2}$ at a rate of $0.6 \pm 0.1 \mu$ moles $\mathrm{m}^{-2} \mathrm{day}^{-1}$. The gas phase oxidation of $\mathrm{SO}_{2}$ was about $0.2 \mu$ moles $\mathrm{m}^{-2}$ day $^{-1}$ on a diel average, peaking at $0.9 \mu$ moles $\mathrm{m}^{-2} \mathrm{day}^{-1}$ in the afternoon. The largest $\mathrm{SO}_{2}$ loss term was in-cloud oxidation to $\mathrm{SO}_{4}^{2-}$ at approximately $2.1 \pm 0.5 \mu$ moles $\mathrm{m}^{-2}$ day $^{-1}$, which appears to balance the $\mathrm{SO}_{2}$ budget and renders other potential removal mechanisms insignificant. With a slightly acidic coarse mode, our order of magnitude estimations of $\mathrm{SO}_{2}$ oxidation by $\mathrm{O}_{3}$ in sea-salt aerosols using measured size distribution yielded negligible rates. Entrainment diluted $\mathrm{SO}_{4}^{2-}$ burden at a rate of $0.5 \pm 0.3 \mu$ moles $\mathrm{m}^{-2} \mathrm{day}^{-1}$, while dry deposition represented an insignificant sink for $\mathrm{SO}_{4}^{2-}$ because little non-sea-salt $\mathrm{SO}_{4}^{2-}$ mass was present in the coarse mode.

Diurnally, our implied $\mathrm{SO}_{2}$ cycle shows a maximum in concentration near sunset due to oxidation of DMS by $\mathrm{OH}$ and a minimum just after sunrise as a result of in-cloud oxidation, with dry deposition being a continuous loss term. This diel pattern is anticorrelated with that of DMS, consistent with previous observations in the remote Pacific. The $\mathrm{SO}_{4}^{2-}$ diel cycle observed on the ship appeared to be related to boundary layer dynamics and the intricately connected incloud production and wet removal. $\mathrm{SO}_{4}^{2-}$ produced in cloud was confined to near cloud level during the day, when the upper and lower parts of the MBL were usually decoupled. As the MBL recoupled after nightfall, the large amount of $\mathrm{SO}_{4}^{2-}$ built up at cloud level was mixed downwards, increasing the concentration at the surface. After peaking in the middle of the night, $\mathrm{SO}_{4}^{2-}$ steadily declined and leveled off for the rest of the day mostly as a result of decoupling and wet removal by precipitation.

Acknowledgements. We thank the National Science Foundation for support of this work through grant ATM-0241611, ATM-0526341, ATM-0744636, and ATM-0745337. Aircraft thermodynamic data and ancillary gas concentrations were provided by NCAR/EOL under sponsorship of the NSF (http://data.eol.ucar.edu/master_list/ ?project=VOCALS). PMEL data were downloaded from http://saga.pmel.noaa.gov/data/download.php?cruise=VOCALS. Special thanks to R.A. Weller, C.W. Fairall, R. Wood, C.S. Bretherton, R.M. Simpson, as well as the crews of $R H B$ and C-130.

Edited by: R. Wood

\section{References}

Allen, G., Coe, H., Clarke, A., Bretherton, C., Wood, R., Abel, S. J., Barrett, P., Brown, P., George, R., Freitag, S., McNaughton, C., Howell, S., Shank, L., Kapustin, V., Brekhovskikh, V., Kleinman, L., Lee, Y.-N., Springston, S., Toniazzo, T., Krejci, R., Fochesatto, J., Shaw, G., Krecl, P., Brooks, B., McKeeking, G., Bower, K. N., Williams, P. I., Crosier, J., Crawford, I., Connolly, P., Covert, D., and Bandy, A. R.: Southeast Pacific atmospheric composition and variability sampled along $20^{\circ} \mathrm{S}$ during VOCALS-REx, Atmos. Chem. Phys. Discuss., 11, 681-744, doi:10.5194/acpd-11-681-2011, 2011.

Andronache, C.: Estimated variability of below-cloud aerosol removal by rainfall for observed aerosol size distributions, Atmos. Chem. Phys., 3, 131-143, doi:10.5194/acp-3-131-2003, 2003.

Andronache, C.: Estimates of sulfate aerosol wet scavenging coefficient for locations in the Eastern United States, Atmos. Environ., 38(6), 795-804, ISSN 1352-2310, doi:10.1016/j.atmosenv.2003.10.035, 2004.

Bandy, A. R., Thornton, D. C., Blomquist, B. W., Chen, S., Wade, T. P., Ianni, J. C., Mitchell, G. M., and Nadler, W.: Chemistry of dimethyl sulfide in the equatorial Pacific atmosphere, Geophys. Res. Lett., 23(7), 741-744, doi:10.1029/96GL00779, 1996.

Bandy, A. R., Thornton, D. C., Tu, F. H., Blomquist, B. W., Nadler, W., Mitchell, G. M., and Lenchow, D. H.: Determination of the 
vertical flux of dimethylsulfide by eddy correlation and atmospheric pressure ionization mass spectrometry (APIMS), J. Geophys. Res., 107(D24), 4743, doi:10.1029/2002JD002472, 2002.

Bates, T. S., Calhoun, J. A., and Quinn, P. K.: Variations in the Methanesulfonate to Sulfate Molar Ratio in Submicrometer Marine Aerosol Particles Over the South Pacific Ocean, J. Geophys. Res., 97(D9), 9859-9865, 1992.

Bates, T. S., Quinn, P. K., Covert, D. S., Coffman, D. J., Johnson, J. E., and Wiedensohler, A.: Aerosol physical properties and processes in the lower marine boundary layer: A comparison of shipboard sub-micron data from ACE-1 and ACE-2, Tellus B, 52, 258-272, 2000.

Bates, T. S., Quinn, P. K., Coffman, D., Schulz, K., Covert, D. S., Johnson, J. E., Williams, E. J., Lerner, B. M., Angevine, W. M., Tucker, S. C., Brewer, W. A., and Stohl, A.: Boundary layer aerosol chemistry during TexAQS/GoMACCS 2006: Insights into aerosol sources and transformation processes, J. Geophys. Res., 113, D00F01, doi:10.1029/2008JD010023, 2008.

Benedict, K. B., Lee, T., and Collett Jr., J. L.: Cloud water composition over the Southeastern Pacific Ocean during the VOCALS Regional Experiment, Atmos. Environ., submitted, 2011.

Bretherton, C. S., Uttal, T., Fairall, C. W., Yuter, S. E., Weller, R. A., Baumgardner, D., Comstock, K., Wood, R., and Rag, G. B.: The EPIC 2001 stratocumulus study, B. Am. Meteorol. Soc., 85(7), 967-977, 2004.

Bretherton, C. S., Wood, R., George, R. C., Leon, D., Allen, G., and Zheng, X.: Southeast Pacific stratocumulus clouds, precipitation and boundary layer structure sampled along $20^{\circ} \mathrm{S}$ during VOCALS-REx, Atmos. Chem. Phys., 10, 10639-10654, doi:10.5194/acp-10-10639-2010, 2010.

Blomquist, B. W., Huebert, B. J., Fairall, C. W., and Faloona, I. C.: Determining the sea-air flux of dimethylsulfide by eddy correlation using mass spectrometry, Atmos. Meas. Tech., 3, 1-20, doi:10.5194/amt-3-1-2010, 2010.

Caldwell, P., Bretherton, C. S., and Wood, R.: Mixed-Layer Budget Analysis of the Diurnal Cycle of Entrainment in Southeast Pacific Stratocumulus, J. Atmos. Sci., 62(10), 3775-3791, 2005.

Chameides, W. L.: The photochemistry of a remote marine stratiform cloud, J. Geophys. Res., 89(D3), 4739-4755, doi:10.1029/JD089iD03p04739, 1984.

Charlson, R. J., Lovelock, J. E., Andreae, M. O., and Warren S. G.: Oceanic phytoplankton, atmospheric sulfur, cloud albedo and climate, Nature, 326, 655-661, 1987.

Charlson, R. J., Schwartz, S. E., Hales, J. M., Cess, R. D., Coakley Jr., J. A., Hansen, J. E., and Hoffman, D. J.: Climate forcing by anthropogenic aerosols, Science, 255, 423-430, 1992.

Clarke, A. D., Li, Z., and Litchy, M.:Aerosol dynamics in the equatorial Pacific marine boundary layer: Microphysics, diurnal cycles and entrainment, Geophys. Res. Lett., 23(7), 733-736, doi:10.1029/96GL00778, 1996.

Clarke, A. D., Davis, D., Kapustin, V. N., Eisele, F., Chen, G., Paluch, I., Lenschow, D., Bandy, A. R., Thornton, D., Moore, K., Mauldin, L., Tanner, D., Litchy, M., Carroll, M. A., Collins, J., and Albercook, G.: Particle nucleation in the tropical boundary layer and its coupling to marine sulfur sources, Science, 282, 89-92, 1998.

de Szoeke, S. P., Fairall, C. W., and Pezoa, S.: Ship Observations of the Tropical Pacific Ocean along the Coast of South America, J. Climate, 22, 458-464, 2008.
Fairall, C. W., Helmig, D., Ganzeveld, L., and Hare, J.: Waterside turbulence enhancement of ozone deposition to the ocean, Atmos. Chem. Phys., 7, 443-451, doi:10.5194/acp-7-443-2007, 2007.

Faloona, I.: Sulfur processing in the marine atmospheric boundary layer: A review and critical assessment of modeling uncertainties, Atmos. Environ., 43(18), 2841-2854, ISSN 1352-2310, doi:10.1016/j.atmosenv.2009.02.043, 2009.

Faloona, I., Lenschow, D., Campos, T., Stevens, B., van Zanten, M., Blomquist, B., Thornton, D., Bandy, A., and Gerber, H.: Observations of Entrainment in Eastern Pacific Marine Stratocumulus Using Three Conserved Scalars, J. Atmos. Sci., 62, 3268-3285, 2005.

Faloona, I., Conley, S., Blomquist, B., Clarke, A., Kapustin, V., Howell, S., Lenschow, D. H., and Bandy, A.: Sulfur dioxide in the tropical marine boundary layer: dry deposition and heterogeneous oxidation observed during the Pacific Atmospheric Sulfur Experiment, J. Atmos. Chem., 63(1), 13-32, doi:10.1007/s10874-010-9155-0, 2010.

Feingold, G., Kreidenweis, S., and Zhang, Y.: Stratocumulus processing of gases and cloud condensation nuclei 1. Trajectory ensemble model, J. Geophys. Res., 103(D16), 19527-19542, 1998.

Hawkins, L. N., Russell, L. M., Covert, D. S., Quinn, P. K., and Bates T. S.: Carboxylic acids, sulfates, and organosulfates in processed continental organic aerosol over the southeast $\mathrm{Pa}$ cific Ocean during VOCALS-REx 2008, J. Geophys. Res., 115, D13201, doi:10.1029/2009JD013276, 2010.

Hegg, D. A.: The importance of liquid-phase oxidation of $\mathrm{SO}_{2}$ in the troposphere, J. Geophys. Res., 20, 3773-377, 1985.

Hind, A. J., Rauschenberg, C. D., Johnson, J. E., Yang, M., and Matrai, P. A.: The use of algorithms to predict surface seawater dimethyl sulphide concentrations in the SE Pacific, a region of steep gradients in primary productivity, biomass and mixed layer depth, Biogeosciences, 8, 1-16, doi:10.5194/bg-8-1-2011, 2011.

Hoffmann, M. R. and Calvert, J. G.: Chemical transformation modules for Eulerian acid deposition models, Volume 2, The Aqueous-Phase Chemistry, EPA/600/3-85/017, US Environmental Protection Agency, Research Triangle Park, NC, 1985.

Hoppel, W. A., Frick, G. M., and Larson, R. E.: Effect of nonprecipitating clouds on the aerosol size distribution in the marine boundary layer. Geophys. Res. Lett., 13(2), 125-128, doi:10.1029/GL013i002p00125, 1986.

Howell, S. G., Clarke, A. D., Shinozuka, Y., Kapustin, V., McNaughton, C. S., Huebert, B. J., Doherty, S. J., and Anderson, T. L.: Influence of relative humidity upon pollution and dust during ace-Asia: Size distributions and implications for optical properties, J. Geophys. Res. Atmos., 111(D6), D06205, doi:10.1029/2004JD005759, 2006.

Huebert, B. J., Wylie, D. J., Zhuang, L., and Heath, J. A.: Production and loss of methanesulfonate and non-sea salt sulfate in the equatorial Pacific marine boundary layer, Geophys. Res. Lett., 23, 737-740, 1996.

Huebert, B. J., Blomquist, B., Hare, J., Fairall, C., Johnson, J., and Bates, T.: Measurement of the sea-air DMS flux and transfer velocity using eddy correlation, Geophys. Res. Lett., 31, L23113, doi:10.1029/2004GL021567, 2004a.

Huebert, B. J., Howell, S. G., Covert, D., Bertram, T., Clarke, A., Anderson, J. R., Lafleur, B. G., Seebaugh, W. R., Wilson, J. C., Gesler, D., Blomquist, B., and Fox, J: PELTI: Measuring the 
Passing Efficiency of an Airborne Low Turbulence Aerosol Inlet, Aerosol Sci. Tech., 38, 803-826, 2004b.

Keene, W. C., Pszenny, A. A. P., Jacob, D. J., Duce, R. A., Galloway, J. N., Schultz-Tokos, J. J., Sievering, H., and Boatman, J. F.: The geochemical cycling of reactive chlorine through the marine troposphere, Global Biogeochem. Cy., 4, 407-430, 1990.

Lana, A., Bell, T., Simó, R., Vallina, S., Ballabrera-Poy, J., Kettle, A., Dachs, J., Bopp, L., Saltzman, E., Stefels, J., Johnson, J., and Liss, P.: An updated climatology of surface dimethlysulfide concentrations and emission fluxes in the global ocean, Global Biogeochem. Cy., 25, GB1004, doi:10.1029/2010GB003850, 2011.

Lilly, D. K.: Models of cloud-topped mixed layers under a strong inversion, Q. J. Roy. Meteor. Soc., 94, 292-309, 1968.

Maahs, H. G.: Sulfur dioxide/water equilibrium between $0^{\circ}$ and $50^{\circ}$ : An examination of data at low concentrations, in Heterogeneous Atmospheric Chemistry, edited by: Schryer, D. R., 187195, AGU, Washington, DC, 1983.

Marshall, J. S. and Palmer, W. M.: The distribution of raindrop with size, J. Meteorol., 5, 165-166, 1948.

Martin, L. and Damschen, D. E.: Aqueous oxidation of sulfur dioxide by hydrogen peroxide at low $\mathrm{pH}$, Atmos. Environ., 15(9), 1615-1621, ISSN 0004-6981, doi:10.1016/00046981(81)90146-3, 1981.

McInnes, L. M., Covert, D. S., Quinn, P. K., and Germani, M. S.: Measurements of chloride depletion and sulfur enrichment in individual sea-salt particles collected from the remote marine boundary-layer, J. Geophys. Res., 99(D4), 8257-8268, doi:10.1029/93JD03453, 1994.

Nicholls, S.: The dynamics of stratocumulus: aircraft observations and comparisons with a mixed layer model, Q. J. Roy. Meteorol. Soc., 110, 783-820, 1984.

Okita, T., Hara, H., and Norio, F.: Measurements of atmospheric $\mathrm{SO}_{2}$ and $\mathrm{SO}_{4}^{2-}$, and determination of the wet scavenging coefficient of sulfate aerosols for the winter monsoon season over the sea of Japan, Atmos. Environ., 30(22), 3733-3739, ISSN 13522310, doi:10.1016/1352-2310(96)00090-8, 1996.

Perry, K. D. and Hobbs, P. V., Further evidence for particle nucleation in clear air adjacent to marine cumulus clouds, J. Geophys. Res., 99(D11), 22803-22818, doi:10.1029/94JD01926, 1994.

Rahn, D. A. and Garreaud, R.: Marine boundary layer over the subtropical southeast Pacific during VOCALS-REx - Part 1: Mean structure and diurnal cycle, Atmos. Chem. Phys., 10, 4491-4506, doi:10.5194/acp-10-4491-2010, 2010.

Sander, S. P., Golden, D. M., Kurylo, M. J., Moortgat, G. K., Wine, P. H., Ravishankara, A. R., Kolb, C. E., Molina, M. J., FinlaysonPitts, B. J., Huie, R. E., and Orkin, V. L.: Chemical Kinetics and Photochemical Data for Use in Atmospheric Studies, Evaluation Number 15, Jet Propulsion Laboratory, Pasadena, CA (available at: http://jpldataeval.jpl.nasa.gov/), 2006.

Schwartz, S. E.: Mass transport limitation to the rate of in-cloud oxidation of $\mathrm{SO}_{2}$ : reexamination in the light of new data, Atmos. Environ., 22, 2491-2499, 1988.

Scott, B. C.: Theoretical estimates of the scavenging coefficient for soluble aerosol particles as a function of precipitation type, rate and altitude, Atmos. Environ., 16, 1753-1762, 1982.

Seinfeld, J. H. and Pandis, S. N.: Atmospheric chemistry and physics: from air pollution to climate change, 2nd edn. WileyInterscience, Hoboken, New Jersey, USA, 2006.

Sievering, H., Boatman, J., Galloway, J., Keene, W., Kim, Y., Luria,
M., and Ray, J.: Heterogeneous sulfur conversion in sea-salt aerosol particles: the role of aerosol water content and size distribution, Atmos. Environ., 25A, 1479-1487, 1991.

Slinn, S. A. and Slinn, W. G. N.: Predictions for particle deposition on natural waters, Atmos. Environ., 14, 1013-1016, 1980.

Stevens, B., Vali, G., Comstock, K., Wood, R., VanZanten, M., Austin, P. H., Bretherton, C. S., and Lenschow, D. H.: Pockets of Open Cells (POCs) and Drizzle in Marine Stratocumulus, B. Am. Meteor. Soc., 86, 51-57, 2005.

Straub, D. J. and Collett, J. L.: An axial-flow cyclone for aircraftbased cloud water sampling, J. Atmos. Ocean. Tech., 21(12), 1825-1839, 2004.

Straub, D. J., Lee, T., and Collett Jr., J. L.: Chemical composition of marine stratocumulus clouds over the eastern Pacific Ocean, J. Geophys. Res., 112, D04307, doi:10.1029/2006JD007439, 2007.

ten Brink, H. M., Schwartz, S. E., and Daum, P. H.: Efficient scavenging of aerosol sulfate by liquid-water clouds, Atmos. Environ., 21(9), 2035-2052, ISSN 0004-6981, doi:10.1016/00046981(87)90164-8, 1986.

Thornton, D. C., Bandy, A. R., Tu, F. H., Blomquist, B. W., Mitchell, G. M., Nadler, W., and Lenschow, D. H.: Fast airborne sulfur dioxide measurements by atmospheric pressure ionization mass spectrometry (APIMS), J. Geophys. Res. Atmos., 107(D22), 4632, doi:10.1029/2002JD002289, 2002.

Tucker, S., Senff, C. J., Weickmann, A. M., Brewer, W. A., Banta, R. M., Sandberg, S. P., Law, D. C., and Hardesty, R. M.: Doppler Lidar Estimation of Mixing Height Using Turbulence, Shear, and Aerosol Profiles, J. Atmos. Ocean. Tech., 26, 673-688, 2009.

Twomey, S.: Aerosols, clouds and radiation, Atmos. Environ A, 25(11), 2435-2442, 1991.

Wesely, M. L. and Hicks, B. B.: Some factors that affect deposition rates of sulfur-dioxide and similar gases on vegetation, J. Air Pollut. Control Assoc., 27(11), 1110-1116, 1977.

Wood, R. and Bretherton, C. S.: Boundary Layer Depth, Entrainment, and Decoupling in the Cloud-Capped Subtropical and Tropical Marine Boundary Layer, J. Climate, 17, 3576-3588, 2004.

Wood, R., Mechoso, C. R., Bretherton, C. S., Weller, R. A., Huebert, B., Straneo, F., Albrecht, B. A., Coe, H., Allen, G., Vaughan, G., Daum, P., Fairall, C., Chand, D., Gallardo Klenner, L., Garreaud, R., Grados, C., Covert, D. S., Bates, T. S., Krejci, R., Russell, L. M., de Szoeke, S., Brewer, A., Yuter, S. E., Springston, S. R., Chaigneau, A., Toniazzo, T., Minnis, P., Palikonda, R., Abel, S. J., Brown, W. O. J., Williams, S., Fochesatto, J., Brioude, J., and Bower, K. N.: The VAMOS Ocean-Cloud-Atmosphere-Land Study Regional Experiment (VOCALS-REx): goals, platforms, and field operations, Atmos. Chem. Phys., 11, 627-654, doi:10.5194/acp-11-6272011, 2011.

Yang, M., Blomquist, B. W., and Huebert, B. J.: Constraining the concentration of the hydroxyl radical in a stratocumulus-topped marine boundary layer from sea-to-air eddy covariance flux measurements of dimethylsulfide, Atmos. Chem. Phys., 9, 92259236, doi:10.5194/acp-9-9225-2009, 2009.

Yang, M., Blomquist, B., Fairall, C., Archer, S., and Huebert, B.: Air-sea Exchange of Dimethylsulfide (DMS) in the Southern Ocean - Measurements from SO GasEx Compared to Temperate and Tropical Regions, J. Geophys. Res., accepted, 2011.

Yin, F., Grosjean, D., and Seinfeld, J.: Photooxidation of 
dimethylsulfide and dimethyldisulfide, I, Mechanism development, J. Atmos. Chem., 11, 309-364, 1990.

Zhuang, L. and Huebert, B. J.: Lagrangian analysis of the total ammonia budget during Atlantic Stratocumulus Transition Experiment/Marine Aerosol and Gas Exchange, J. Geophys. Res., 101(D2), 4341-4350, doi:10.1029/95JD02467, 1996.
Zuidema, P., Westwater, E., Fairall C., and Hazen, D.: Ship-based Liquid Water Path Estimates in Marine Stratocumulus, J. Geophys. Res., 110, D20206, doi:10.1029/2005JD005833, 2005. 